\title{
Describing the Body Condition Score Change Between Successive Calvings: A Novel Strategy Generalizable to Diverse Cohorts
}

\author{
J. R. Roche, ${ }^{\star 1,2}$ D. P. Berry,† J. M. Lee, ${ }^{*}$ K. A. Macdonald, ${ }^{*}$ and R. C. Boston‡ \\ *Dexcel, Hamilton, New Zealand \\ †Teagasc Moorepark, Fermoy, Co. Cork, Ireland \\ łDepartment of Clinical Studies, New Bolton Center, University of Pennsylvania, Kennett Square 19104
}

\begin{abstract}
The objective of this study was to explore the derivation of a mathematical model that adequately describes the intercalving body condition score (BCS) profile in dairy cows and is robust and applicable to different animal cohorts. The data used to generate the function were 75,352 daily BCS records across 3,209 lactations in 1,172 cows from a research herd in New Zealand. Mean daily BCS (scale 1 to 10) across all data were plotted and 4 distinct phases were observed. The functional form used to describe the pattern and quantify its features comprised the sum of the 4 phase functions created from intercepts, rates of change, approximate timing of phase transition points, and the sharpness of these transition points in the BCS profile. The generality and applicability of the described model were tested across substrata of BCS at calving and parity. A second data set consisting of a multiyear study comparing cows fed a total mixed ration (TMR) or grazing fresh pasture was compiled from a different research farm. This data set consisted of 4,112 BCS records from 211 lactations on 95 cows. The third data set was a collation of data from another multiyear experiment comparing animal performance under different stocking rates. The data set consisted of 12,414 BCS test-day records on 564 lactations from 287 cows. The presented model is robust and applicable to different animal cohorts, explaining between 29 and $79 \%$ of variation depending on the cohort studied. A notable second period of negative energy balance was evident in all grazing cows during midlactation, irrespective of calving BCS, parity, or stocking rate, but did not appear in cows fed TMR. The amount of BCS lost postcalving and nadir BCS were positively correlated with calving BCS, with fatter cows at calving losing more BCS postcalving but remaining at a greater
\end{abstract}

\footnotetext{
Received November 5, 2006.

Accepted May 9, 2007.

${ }^{1}$ Corresponding author: john.roche@utas.edu.au

${ }^{2}$ Current address: University of Tasmania, PO Box 3523, Burnie, Tasmania 7320, Australia.
}

BCS at nadir. Primiparous cows calved at a greater BCS than multiparous cows, as dictated by management protocols, but they failed to regain BCS postnadir as effectively as their multiparous counterparts. Results may highlight the need for preferential feeding of younger cows during late lactation, at least in grazing systems, to ensure that they achieve the required calving BCS at second calving. Cows receiving TMR lost BCS at a slower rate than cows on pasture but for a longer period; the amount of BCS lost between calving and nadir did not differ between the different feeding treatments. Calving BCS declined with increasing stocking rate, and the rates of both loss and gain were negatively affected by stocking rate. The presented model accurately identified biological attributes of the intercalving BCS profile of different groups of cows.

Key words: body condition score, model, profile, nutrition

\section{INTRODUCTION}

Despite the recognized effects of BCS and BCS change on milk production (Waltner et al., 1993; Roche et al., 2007b), cow health (Roche and Berry, 2006; Berry et al., 2007), and fertility (Buckley et al., 2003; Roche et al., 2007a), little has been done to provide statistical tools to relate imposed experimental treatments to intercalving BCS profiles (Roche et al., 2006). This is despite the abundance of functions describing lactation profiles for milk yield (Wood, 1976; Wilmink, 1987) as well as the reported effect of imposed treatments on these lactation profiles (Roche et al., 2006).

The importance of BCS has been known for decades. Traditionally, the time of most concern was at calving, with improvements in production- and nonproductionrelated traits with increasing BCS up to BCS 3.0 (5.0point scale) and reduced milk production, health, and some reproduction traits in cows calving at BCS $>3.5$ (Waltner et al., 1993; Roche et al., 2007a,b). However, in recent years BCS at breeding and the loss of BCS between parturition and breeding have gained considerable attention because of their negative association 
with reproductive performance (Beam and Butler, 1999; Buckley et al., 2003; Roche et al., 2007a). An understanding of how BCS changes with time and management, and how it influences production, fertility, and health could potentially help animal scientists develop systems that result in greater financial return to dairy producers. Similarly, changes in BCS, as measured over several weeks, provide useful information about the cow's current nutrient intake relative to its requirements, and allow feeding decisions to be made more effectively.

Using mathematical functions to describe the process of BCS change minimizes random variation while simultaneously capturing the profile of interest in distinct parameters that quantify biological processes. Many researchers have fitted such functions to describe series of milk test-day records (Wood, 1976; Wilmink, 1987; Grossman et al., 1999), and although functions have been used to describe the profile of BCS change (Weigel et al., 1992; Coffey et al., 2002; Friggens et al., 2004; Banos et al., 2005), with the exception of Friggens et al. (2004) the parameters do not directly reflect changes in BCS, and the model of Friggens et al. (2004) was tested only in nongrazing cows. If such a function were to be developed, it would provide a vehicle to identify cows from among their cohort that are "at risk" of BCS-associated health and reproductive disorders, and reduced production. The objective of the current study was to develop a mathematical model that accurately describes the intercalving BCS profile for dairy cows across a diverse range of cow strata and farm systems.

\section{MATERIALS AND METHODS}

\section{Model Development}

Data. Data on cow number, year of birth, parity number, and associated calving dates were extracted from the Dexcel research database on 3,209 lactations from 1,172 cows. All cows resided at No. 2 Dairy, Dexcel, Hamilton, New Zealand, between 1986 and 2004. Twelve percent of the cows in the data set were Jerseys, with the remainder being Holstein-Friesians. The proportions of lactations within each parity were $0.27,0.20$, $0.16,0.12,0.09$, and 0.16 for parities $1,2,3,4,5$, and $\geq 6$, respectively. Calving was seasonal, with day of the year at calving varying from May 31 to October 17; the median day of the year at calving was July 26. Across the data set, average $( \pm$ SD) 270 -d milk yield was 4,766 (874), and average $( \pm \mathrm{SD}) 270$-d milk fat, protein, lactose concentrations were $4.93(0.69), 3.60(0.29)$, and 4.84 (0.20), respectively. Body condition score was assessed within 1 wk of calving, and every 2 wks during the intercalving period. Days postcalving to the last BCS record within parity varied from 11 to $379 \mathrm{~d}$; the median was $344 \mathrm{~d}$. One of the strengths of the current data set was the period of time included (19 yr) and the fact that only 4 trained BCS assessors were used over the entire period.

Experimental Station. The No. 2 Dairy farm has been used for farm systems-based research since the early 1940 s, and the period in question incorporated research comparing the profitability of HolsteinFriesian and Jersey heifers under different grazing systems, different pasture species and cultivars, different grazing rotation lengths, and systems that optimized the use of nitrogen fertilizer and supplementary feeds, as well as research to determine the most profitable stocking rate for grazing dairy systems. Although the data have been collated from one physical location, the data set incorporates $19 \mathrm{yr}$ of data from more than 64 research treatment herds undertaken over multiple lactations (141 different herd $\times$ year treatment herds). The system of milk production was seasonal, with approximately $50 \%$ of cows calving in $2 \mathrm{wk}, 40 \%$ calving in the next $4 \mathrm{wk}$, and the remaining cows calving during wk 7 and 8. Any cows whose planned calving date was later than wk 8 were hormonally induced ( $8 \%$ of data set) to calve during wk 7 and 8 using a 2 -step combination of dexamethasone (Opticortenol S, Novartis Animal Health, Basel, Switzerland; Voren, Boehringer-Ingelheim, Berkshire, UK) and prostaglandin (Estrumate, Schering-Plough Coopers, Wellington, New Zealand), provided they had low SCC before dry-off $(<200,000$ cell $/ \mathrm{mL}$ ), they were in a BCS of 5.0 (on a 10.0-point scale) or greater, and their blood $\mathrm{Mg}(>0.8$ $\mathrm{mmol} / \mathrm{L}$ ) and $\gamma$-glutamyl transferase (15 to $22 \mathrm{U} / \mathrm{L}$ of plasma) levels measured the week prior to planned induction did not indicate health concerns.

All herds were rotationally grazed. In general, herbage was grazed when between 2.0 and 3.0 leaves had regrown on the majority of perennial ryegrass tillers (approximately 2,500 kg of DM/ha in spring, 4,000 kg of DM/ha in summer, and 3,000 kg of DM/ha in autumn and winter-all measurements were to ground level). Postgrazing residuals approximated $40 \mathrm{~mm}$ throughout the year. Detailed accounts of management decision rules are provided by Macdonald and Penno (1998).

BCS Measurements. In all cases, BCS was assessed by palpating individual body parts and an average score was recorded on a 10-point scale, where 1 was emaciated and 10 was obese (Roche et al., 2004). The anatomical regions palpated included the thoracic and vertebral region of the spinal column (chine, loin, and rump), the ribs, the spinous processes (loin), the tuber sacrale (hip or hook bones), the tuber ischii (pin bones), the anterior coccygeal vertebrae (tail head), and the thigh region (Roche et al., 2004). In total, 75,352 records were avail- 
able for inclusion in the analysis. Days postcalving varied from 1 to 360 and parity number varied from 1 to 12 .

\section{Function Fitting}

Preliminary analyses were undertaken on the raw BCS records to elucidate the general shape of the BCS profile across the intercalving interval. Scatter plots of mean daily BCS against days postcalving were examined graphically using the entire data set, and were examined across alternative strata of parity, year of birth, and BCS at calving. The general BCS intercalving profile was consistent across strata and was certainly representative of different cohorts.

Body condition score, assessed every other week, was averaged by DIM to obtain the daily mean BCS. Figure 1 presents a scatter plot of mean daily BCS using the entire data set. Four distinct phases were observed, reflecting different stages within the intercalving profile. The first and third phases were declining phases and were modeled as the product of a linear and logistic function; the second and fourth phases were, by contrast, inclining phases and were also modeled using a complex logistic function. "Phase transition parameters" were used to allow for either rapid or slow phase shifts at the troughs and peaks near where the lines in Figure 1A intersect. The influence of these phase transition parameters on the adjacent phases of the intercalving profile, and the sensitivity of the BCS predictions to adjustments in the phase transition parameters are described in the results section.

A separate function was derived for each phase, with all phases summed to give the final function, hereafter referred to as the Roche-Berry-Boston (RBB) function. Equations [1] to [4] describe the partial functions for the 4 phases (phase 1 , phase 2 , phase 3 , and phase 4 ) of the intercalving profile illustrated in Figure 1. All 4 phase functions were summed to give the final function (equation [5]):

$$
\begin{gathered}
B C S_{t 1}=\frac{I_{1}+S L_{1} \cdot t}{1+\exp \left[-P T_{1} \cdot\left(T T_{1}-t\right)\right]}, \\
B C S_{t 2}=\left(I_{2}+S L_{2} \cdot t\right) \cdot \\
\left(\frac{1}{\left\{1+\exp \left[P T_{1} \cdot\left(T T_{1}-t\right)\right]\right\} \cdot\left\{1+\exp \left[-P T_{2} \cdot\left(T T_{2}-t\right)\right]\right\}}\right) \\
B C S_{t 3}=\left(I_{3}+S L_{3} \cdot t\right) \cdot \\
\left(\frac{1}{\left\{1+\exp \left[P T_{2} \cdot\left(T T_{2}-t\right)\right]\right\} \cdot\left\{1+\exp \left[-P T_{3} \cdot\left(T T_{3}-t\right)\right]\right\}}\right) \\
B C S_{t 4}=\frac{I_{4}+S L_{4} \cdot t}{1+\exp \left[P T_{3} \cdot\left(T T_{3}-t\right)\right]},
\end{gathered}
$$

$$
R B B=B C S_{t 1}+B C S_{t 2}+B C S_{t 3}+B C S_{t 4},
$$

where $t$ represents days postcalving, $I_{x}$ is the intercept (BCS units) of phase $x, S L_{x}$ is the linear slope (BCS change/d) of the profile in phase $x, P T_{x}$ is the phase transition point leaving phase $x$, and $T T_{x}$ is the turning time (d) of the profile between phase $x$ and phase $x+1$.

Starting values for the parameters in the RBB function were derived by fitting robust regressions (Huber, 1964) through each of the phases separately in Stata 9.0 (StataCorp, 2005). These starting values, with their associated errors, were entered into WinSAAM (Stefanovski et al., 2003) and the RBB function was fitted using a Gauss-Newton generalized least squares procedure. Forward differencing was used to determine the rate of change in BCS at each day. The fractional sensitivity of the BCS predictions to each of the parameters of the RBB function at $\mathrm{d} t$ postcalving was determined by equation [6],

$$
\text { sensitivity }_{t, \theta}=\frac{\partial \log _{e} B C S(t, \theta)}{\partial \log _{e} \theta},
$$

where $\theta$ is the RBB parameter under investigation.

An algorithm was devised to predict consistent parameter values accurately and repeatably. The algorithm involved initially invoking robust linear regression separately within each phase of the BCS profile. The turning times were calculated from the intercept and slope terms of the adjacent phases. All starting values were entered into WinSAAM, the phase transition points were fixed to 0.1 , and the function was fitted. Following convergence, all parameters, with the exception of the phase transition points, were fixed and the RBB function was again fitted. Finally, all parameters of the RBB function were allowed to vary and the final estimates of the parameters were obtained. This systematic procedure yielded accurate (when graphically compared with the raw data) and reproducible parameter estimates.

\section{Data Sets Used for Validation}

Three alternative data sets were used to investigate the applicability of the RBB model to stratified data originating from contrasting systems of milk production. The first data set was that used to generate the model. Only Holstein-Friesian animals calving between 1986 and 2000 were retained from the first data set; 52,581 BCS test-day records from 2,064 lactations on 780 cows remained. Only data up to $360 \mathrm{~d}$ postcalving were retained. Each lactation was allocated into strata separately on the basis of both BCS at calving and cow parity. Body condition score at calving was defined as 
A

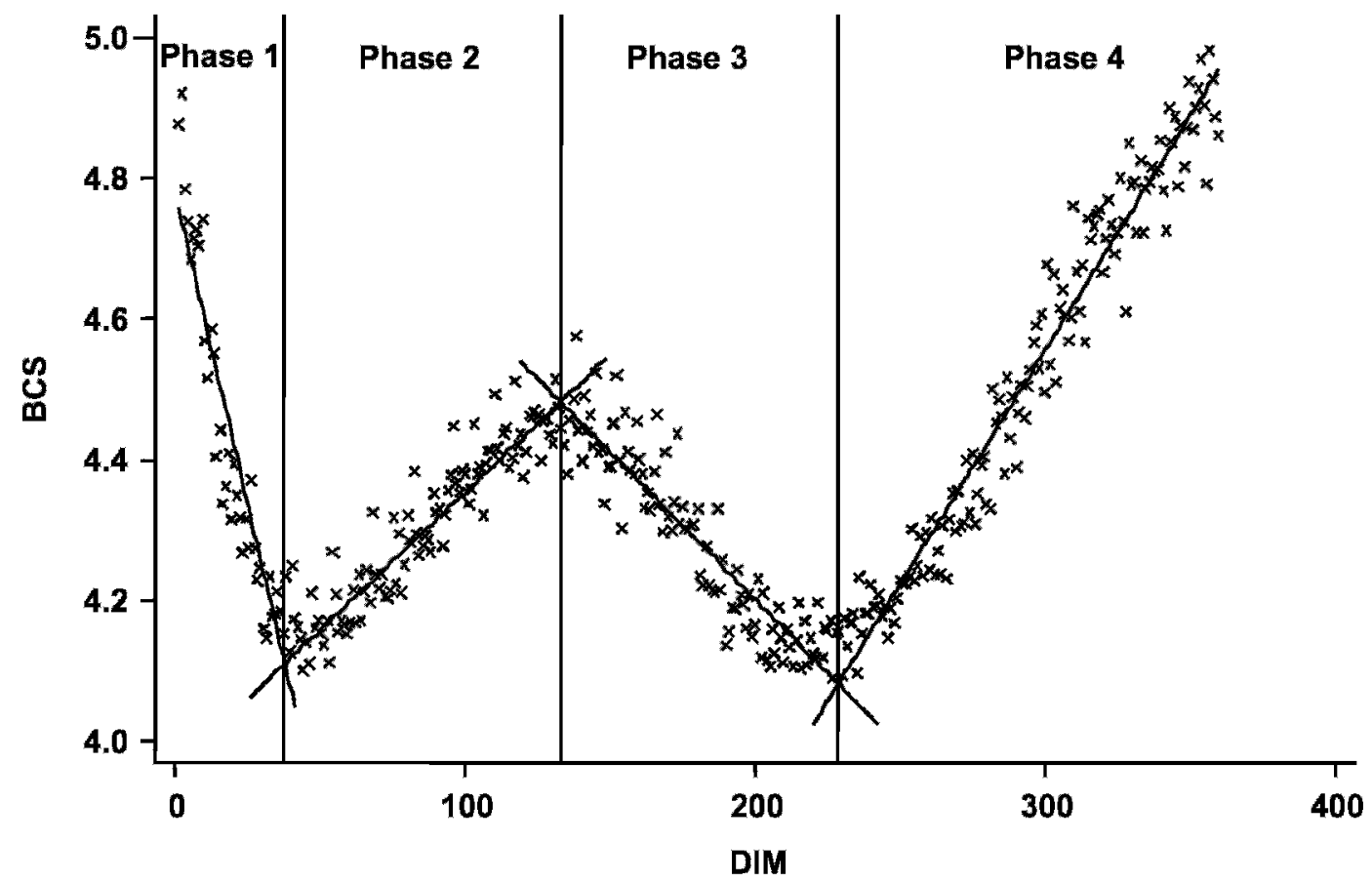

B

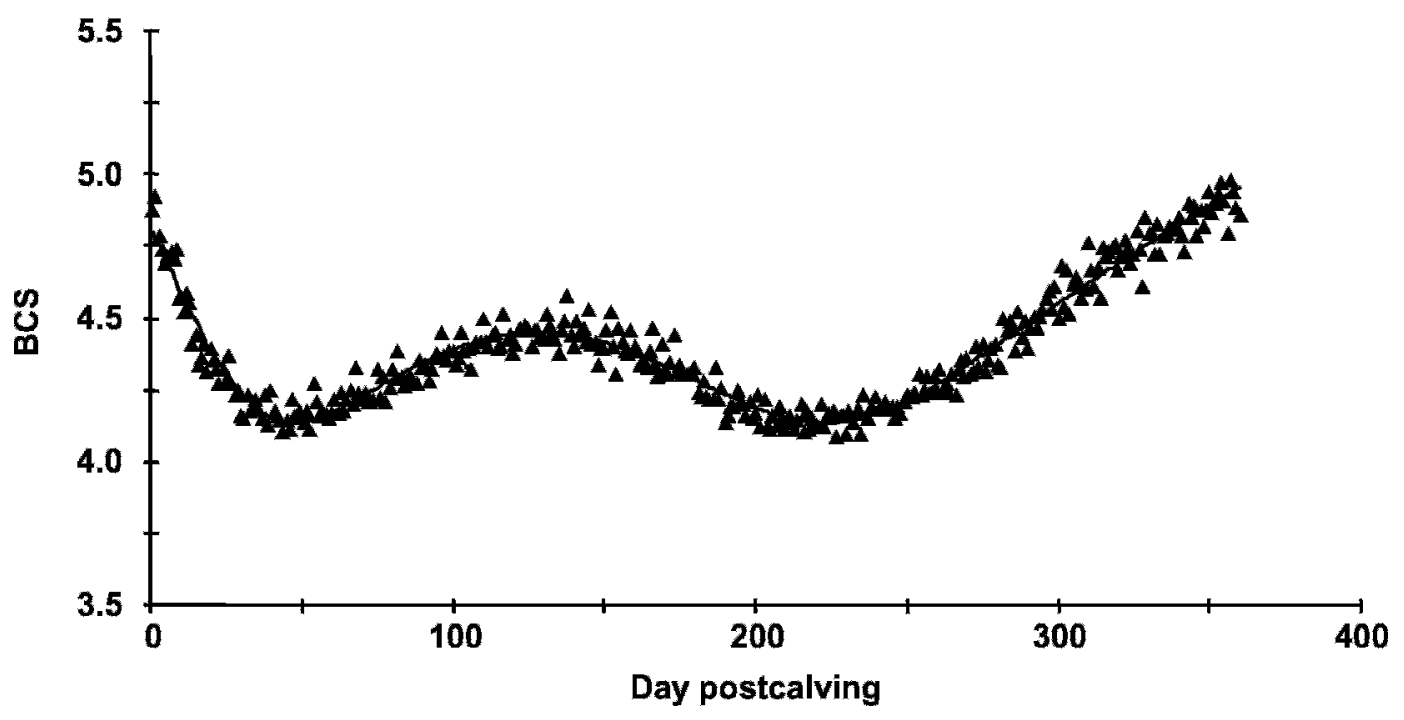

Figure 1. Mean daily BCS $(\times)$ across all data (A) with the fitted robust linear regression lines for phases $1,2,3$, and 4, and (B) the Roche-Berry-Boston model fitted to the raw data. Phases 1, 2, 3, and 4 refer to the initial postcalving decline phase, the subsequent postnadir incline phase, the midlactation decline phase, and the subsequent incline phase in late lactation, respectively. Body condition score was recorded on a 1 to 10 scale (Roche et al., 2004).

the first BCS record within $7 \mathrm{~d}$ postcalving. Little data were available on cows calving at extreme BCS; therefore, cows with a calving BCS of 3.0 and 3.5 BCS units or 6.0 and 6.5 BCS units were assigned separately to individual strata. Between these extremes, strata were in half-unit increments. Strata were therefore 3.0 to $3.5,4.0,4.5,5.0,5.5$, or 6.0 to 6.5 BCS units. Lactations that did not have a BCS record in the first week of lactation, or in which BCS at calving was $<3.0(\mathrm{n}=2)$ or $>6.5(\mathrm{n}=6)$ BCS units were not included in the analysis of BCS at calving. The frequency of the number of lactations and BCS records within each stratum is summarized in Table 2. Parity was recoded as parities 1 to 5 separately, whereas parities 6,7 , and 8 were 
grouped into one parity stratum $(\geq 6.0)$. The frequency of number of lactations and BCS records within parity stratum are summarized in Table 3.

The second data set originated from a study at No. 1 Dairy, Dexcel, Hamilton, New Zealand, between 1998 and 2002, inclusive (Kolver et al., 2002). The objective of that study was to compare 2 contrasting genotypes of mixed-age Holstein-Friesian dairy cows fed either predominantly grazed pasture or a TMR. HolsteinFriesian cows of New Zealand $(n=50)$ or North American $(n=45)$ origin were randomly allocated to treatments of grazed pasture $(\mathrm{n}=49)$ or TMR $(\mathrm{n}=46)$ in a $2 \times 2$ factorial arrangement. The first year consisted of all primiparous animals with an equal number of primiparous replacements entering each treatment group in subsequent years. All animals were balanced across treatment group for breeding worth (i.e., the genetic merit index for profitability in New Zealand), and within genotype, treatments were balanced for sire and cow BW. The final data set consisted of 4,112 BCS records from 211 lactations on 95 cows. Additional details regarding treatments and diets are presented by Kolver et al. (2002).

The third data set was a collation of data from a multiyear experiment (1998 to 2000) comparing animal performance at different stocking rates under grazing. The trial consisted of 10 treatment farmlets, with 5 stocking rates $(2.2,2.7,3.2,3.7$, and $4.3 \mathrm{cows} / \mathrm{ha})$ replicated twice. Detailed accounts of management decision rules are provided by Macdonald and Penno (1998). Briefly, the system of milk production was seasonal, with approximately $50 \%$ of cows calving in $2 \mathrm{wk}, 40 \%$ calving in the next $4 \mathrm{wk}$, and the remaining cows calving during wk 7 and 8 . All herds were rotationally grazed. In general, the pasture (predominantly perennial ryegrass; Lolium perenne L.) was grazed when between 2.0 and 3.0 new leaves had regrown on the majority of perennial ryegrass tillers (approximately $2,500 \mathrm{~kg}$ of $\mathrm{DM} / \mathrm{ha}$ in spring, $4,000 \mathrm{~kg}$ of DM/ha in summer, and $3,000 \mathrm{~kg}$ of DM/ha in autumn and winter-all measurements were to ground level). Postgrazing residuals approximated $40 \mathrm{~mm}$ throughout the year.

The amount of pasture allocated to maintain the pregrazing and residual mass described above was determined by the amount of pasture available and the daily growth rates at the time. Pasture surplus to requirements, as defined by the previously reported desired pregrazing and postgrazing pasture mass, was harvested for silage. If sufficient pasture was not available to maintain this grazing rotation, pasture silage conserved on the treatment farmlet was offered as a supplement. The final data set consisted of 12,414 BCS testday records on 564 lactations from 287 cows.
Table 1. Starting values (SV) for each of the function parameters ${ }^{1}$ (with the exception of the phase transition parameters) obtained from the robust regression, and estimates derived from the Roche-BerryBoston (RBB) function when fitted to the entire data set used for model development

\begin{tabular}{lrrc}
\hline Parameter & SV & RBB & $\mathrm{SE}^{2}$ \\
\hline$I_{1}$, BCS units & 4.77 & 4.85 & 0.011 \\
$S L_{1}$, BCS units $\times 1,000$ & -17.64 & -22.69 & 0.591 \\
$I_{2}$, BCS units & 3.96 & 3.98 & 0.010 \\
$S L_{2}$, BCS units $\times 1,000$ & 3.88 & 3.66 & 0.106 \\
$I_{3}$, BCS units & 5.04 & 5.02 & 0.025 \\
$S L_{3}$, BCS units $\times 1,000$ & -4.19 & -4.77 & 0.160 \\
$I_{4}$, BCS units & 2.57 & 2.69 & 0.026 \\
$S L_{4}$, BCS units $\times 1,000$ & 6.61 & 6.31 & 0.074 \\
$P T_{1}, \times 1,000$ & & 61.1 & 3.56 \\
$P T_{2}, \times 1,000$ & & 33.7 & 1.02 \\
$P T_{3}, \times 1,000$ & 38 & 41.6 & 2.29 \\
$T T_{1}$, d & 133 & 37 & 0.01 \\
$T T_{2}, \mathrm{~d}$ & 229 & 133 & 0.01 \\
$T T_{3}, \mathrm{~d}$ & & 228 & 0.01 \\
\hline
\end{tabular}

${ }^{1} I_{x}$ is the intercept (BCS units) of phase $x, S L_{x}$ is the linear slope (BCS change/d) of the profile in phase $x, P T_{x}$ is the phase transition point leaving phase $x$, and $T T_{x}$ is the turning time (d) of the profile between phase $x$ and phase $x+1$.

${ }^{2}$ Standard error of the RBB estimates.

Parameters were estimated for each stratum using the algorithm previously described. The root mean square error (RMSE) of the function fit, calculated as the standard deviation of the residuals between the daily raw BCS and the corresponding predicted daily BCS, was calculated across strata. The proportion of variation in mean daily BCS explained by the RBB function was also calculated across strata. The residuals were plotted against the predicted values to investigate the possible existence of systematic bias (StPierre, 2001).

\section{RESULTS}

\section{Parameter Values and Sensitivity of Estimates to Parameters}

A summary of the parameter starting values obtained from robust regression, and the final parameter estimates and respective standard errors from fitting the function to the data set for model development are presented in Table 1 . The starting values obtained from robust regression were very good approximations of the final values obtained from the RBB function; a similar conclusion was evident when the data were divided into strata. This approach did not readily facilitate the approximation of the phase transition parameters. Nevertheless, the efficient approximation of the starting values for the function using robust regression highlights the advantage of this technique in estimating starting values for use with this function. 
Fractional sensitivities of predicted BCS, across days postcalving, to the intercept parameters of the first $\left(I_{1}\right)$ and second $\left(I_{2}\right)$ partial functions and the slope parameters of the first $\left(S L_{1}\right)$ and second $\left(S L_{2}\right)$ partial functions are presented in Figure 2A; sensitivities of the intercept parameters of the third $\left(I_{3}\right)$ and fourth $\left(I_{4}\right)$ partial functions and the slope parameters of the third $\left(S L_{3}\right)$ and fourth $\left(S L_{4}\right)$ partial functions are presented in Figure $2 \mathrm{~B}$, and the first $\left(T T_{1}\right)$, second $\left(T T_{2}\right)$, and third $\left(T T_{3}\right)$ turning time parameters across days postcalving are presented in Figure 2C. The sensitivities of BCS predictions to the phase transition parameters of the RBB function were relatively small, varying from -0.09 to 0.04 and are thus not presented graphically. The low sensitivity of these parameters is desirable because starting values are not readily estimated; thus, a low sensitivity implies minimal bias and corruption of the other function parameters.

Although BCS at calving is largely a function of the first $\left(I_{1}\right)$ intercept term, Figure 2 highlights that the second $\left(I_{2}\right)$ intercept term also plays a minor role. In comparison, BCS at the first nadir is jointly a function of $I_{1}$ and $I_{2}$. With forward differencing, the timing of first nadir across the entire data set was $48 \mathrm{~d}$, whereas the timing of the first peak and second nadir was 129 and $223 \mathrm{~d}$, respectively. These values can be entered into the RBB function to extract the BCS at the respective days postcalving, coinciding with nadir and peak BCS. Based on the entire data set, BCS at first nadir, at midlactation peak, and at second nadir were 4.13, 4.45, and 4.14 BCS units, respectively.

The RBB function also consists of 4 slope terms, representing the initial postcalving linear rate of decline in BCS $\left(S L_{1}\right)$, the postnadir linear rate of incline in BCS $\left(S L_{2}\right)$, and the subsequent linear rate of decline $\left(S L_{3}\right)$ and incline $\left(S L_{4}\right)$, respectively. Across all cows, the linear daily rate of decline immediately postcalving was $0.02269 \mathrm{BCS}$ units/d; the actual decline at any point in time deviated slightly from this because of the influence of the other function parameters (Figure 2). Three phase transition parameters were included in the RBB function to accommodate differentials in the rate of change from a descending phase to an ascending phase $\left(P T_{1}\right.$ and $\left.P T_{3}\right)$, and vice versa $\left(P T_{2}\right)$. The impact of varying the phase transition rates in the function is illustrated in Figure 3, using the first phase transition parameter as an example. As $P T_{1}$ increases, so does the speed at which the declining phase changes to an ascending phase. This results in minor changes to the slope adjacent to the phase transition point in question and to the respective intercepts (Figure 3).

The rate of change and the fractional rate of change in BCS were attained from the first derivative of the $\mathrm{RBB}$ function (Figure 4). The rate of BCS change por- trays the change in energy balance between 2 successive calvings, portraying a maximum negative energy balance (NEBAL) during wk 1 of lactation. The scale of the negative NEBAL subsequently declines until $d$ 48 postcalving, when energy balance becomes positive. A second NEBAL occurs at 129 d postcalving and reaches its greatest point at approximately $d 179$, before becoming positive again at $d 223$. Figure 4 also shows the fractional rate of depletion of energy stores, showing the greatest depletion during the first $10 \mathrm{~d}$ postcalving and the greatest rate of adipocyte and muscle replenishment at $d 286$ postcalving.

A randomly distributed scatter plot of the residuals against the predicted BCS values at each day postcalving was observed for the entire data set as well as the individual strata investigated.

\section{Model Fit to Strata Defined by BCS at Calving}

Table 2 summarizes the parameters of the RBB model for strata defined by BCS at calving. The fit of the RBB model to the raw data is illustrated in Figure 5 for each stratum, and a comparison of strata differing in calving BCS is presented in Figure 6. Across all strata, the RMSE of the model fit varied from 0.10 to 0.35 BCS units. The proportion of variation explained $\left(r^{2}\right)$ of the fit varied from 30 to $79 \%$.

Predicted BCS at the first intercept $\left(I_{1}\right)$, the major determinant of BCS at calving, closely reflected the calving BCS used in the definition of the strata. The BCS at calving used to stratify animals into cohorts was assumed to be the first BCS postcalving. Considering that the BCS at calving for these strata would be expected to be marginally lower because days postcalving at the first BCS observation varied from 1 to 7 , the predicted values are encouraging. As indicated by the various solutions for the parameters related to the intercepts, the ranking of strata for BCS at calving was identical to that at first nadir, second peak, and second nadir. This is illustrated in Figure 6 by the distinct absence of profile crossover. The corresponding BCS at first nadir were 3.4, 3.8, 4.0, 4.3, 4.4, and 4.9 BCS units for calving BCS strata $\leq 3.5,4.0,4.5,5.0,5.5$, and $\geq 6.0$, respectively.

However, the parameters relating to the slope of the BCS profiles revealed that the rate of BCS loss immediately postcalving $\left(S L_{1}\right)$ was inversely $(P<0.001)$ related to BCS at calving, reflecting an increased rate of loss in early lactation with increased calving BCS. In addition, calving BCS was negatively associated $(P<0.01)$ with both the rate of BCS increase $\left(S L_{2}\right)$ and the amount of BCS gained between the postcalving nadir and the midlactation peak; the rate of BCS gain and the amount 

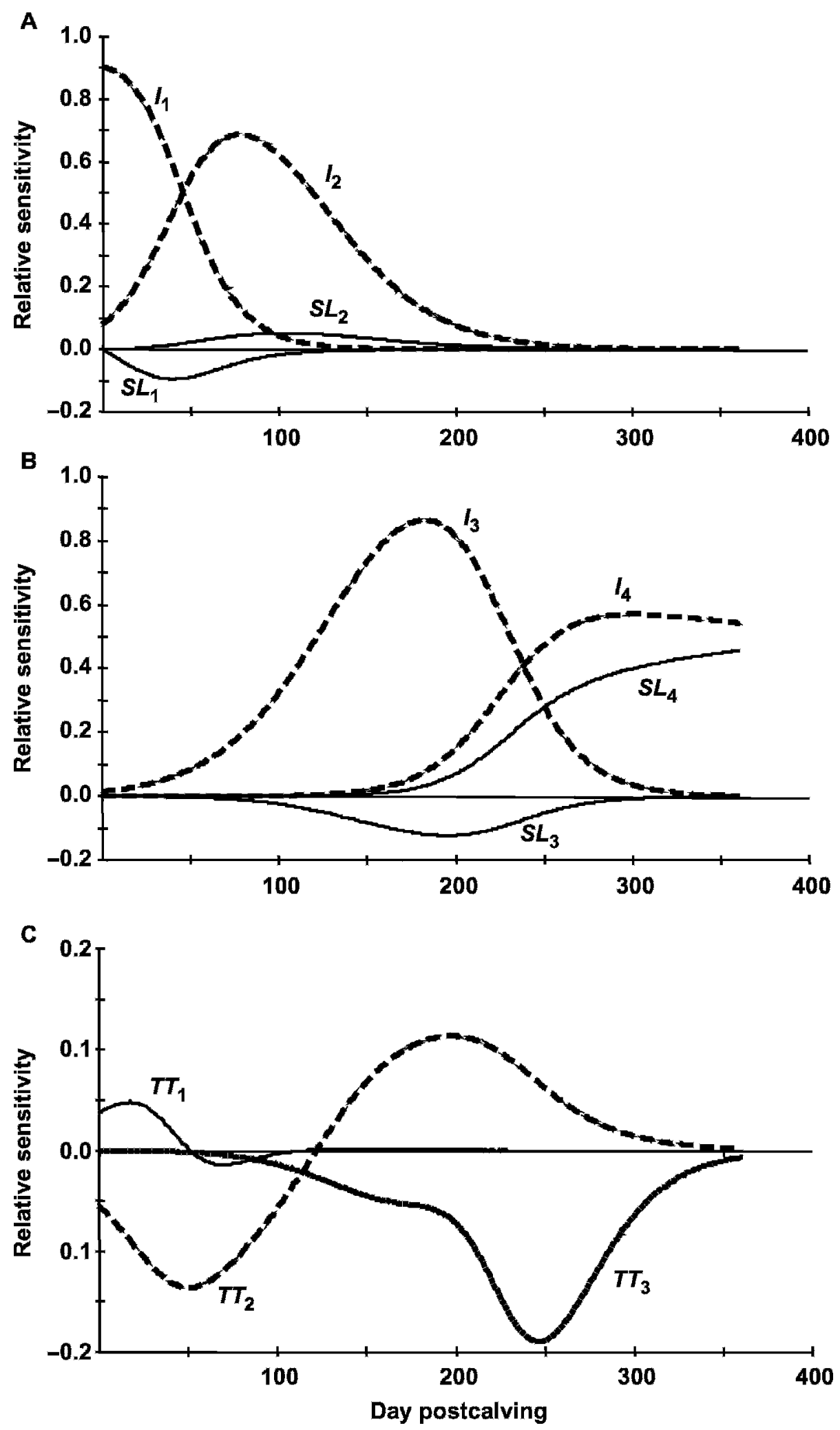

Figure 2. Sensitivities across days postcalving of predicted BCS to (A) the intercept parameters of the first $\left(I_{1}\right)$ and second $\left(I_{2}\right)$ partial functions and the slope parameters of the first $\left(S L_{1}\right)$ and second $\left(S L_{2}\right)$ partial functions, (B) the intercept parameters of the third $\left(I_{3}\right)$ and fourth $\left(I_{4}\right)$ partial functions and the slope parameters of the third $\left(S L_{3}\right)$ and fourth $\left(S L_{4}\right)$ partial functions, and $(\mathrm{C})$ the first $\left(T T_{1}\right)$, second $\left(T T_{2}\right)$, and third $\left(T T_{3}\right)$ turning time parameters across days postcalving. 


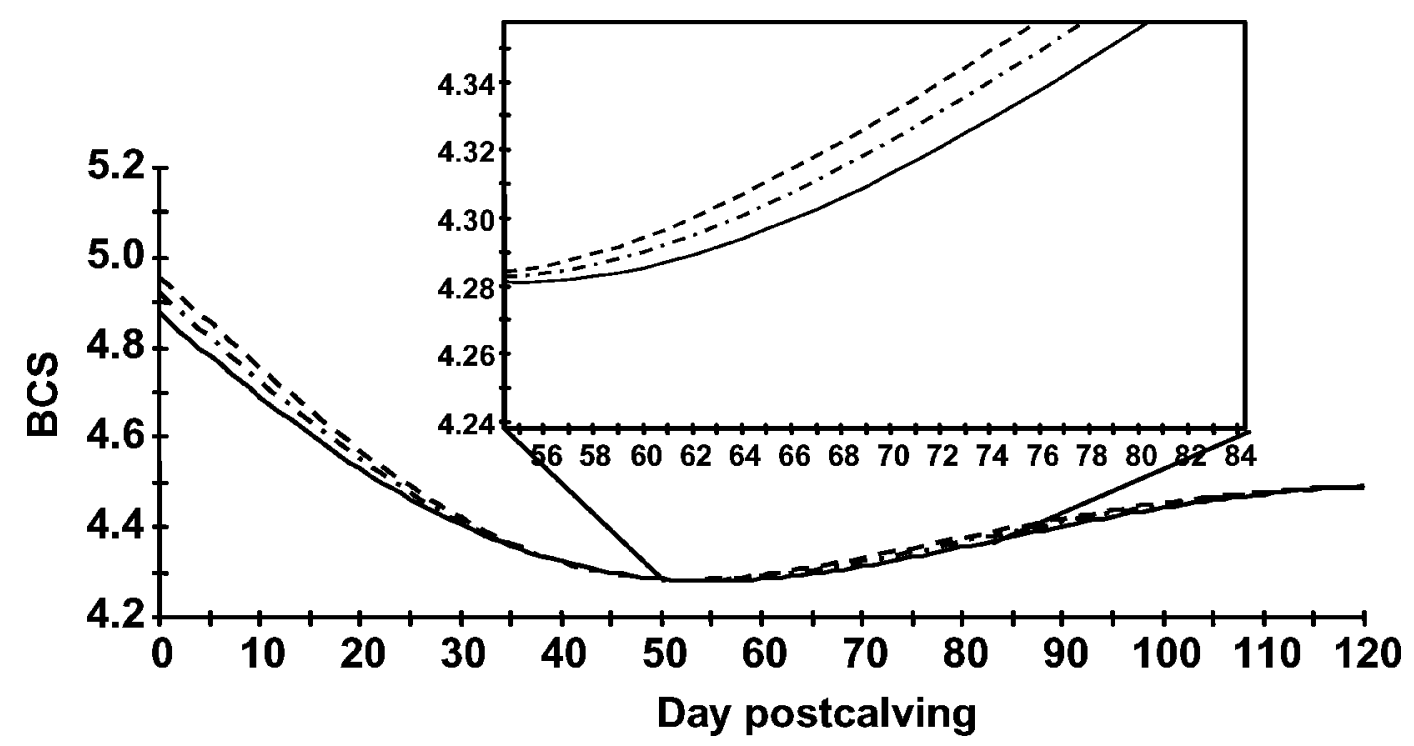

Figure 3. Effect of alternative values for phase transition point 1 ( $P T_{1}$; equation [1] in text) of $0.04(-), 0.05(\cdot-\cdot-\cdot)$, and 0.06 $(----)$ on the shape of the BCS profile.

of BCS gained decreased with increasing calving BCS. Consequently, although the ranking of BCS remained the same relative to calving BCS through the intercalving period, the difference in BCS between strata declined as the lactation progressed. The difference of 2.6 BCS units $(P<0.001)$ between the highest and lowest BCS stratum at calving (first intercept) had declined to $0.98 \mathrm{BCS}$ units $(P<0.001)$ at the fourth intercept (second nadir). Calving BCS did not appear to affect BCS change in midlactation, with $S L_{3}$ and $S L_{4}$ not affected by calving BCS.
Forward differencing revealed a quadratic effect $(P$ $<0.05$ ) of BCS at calving on DIM to first nadir, with DIM to nadir declining at an increasing rate with decreasing calving BCS. The timing of nadir occurred at 24,38 , $41,42,43$, and 43 DIM in cows calving at $\leq 3.5,4.0,4.5$, $5.0,5.5$ and $\geq 6.0$ BCS units, respectively. In comparison, the timing of the midlactation peak in BCS was inversely related to BCS at calving, becoming earlier with increasing calving BCS; the midlactation peak $\mathrm{BCS}$ varied from $122 \mathrm{~d}$ in cows calving at $\mathrm{BCS} \geq 6.0$ to $143 \mathrm{~d}$ in cows calving at BCS $\leq 3.5$.

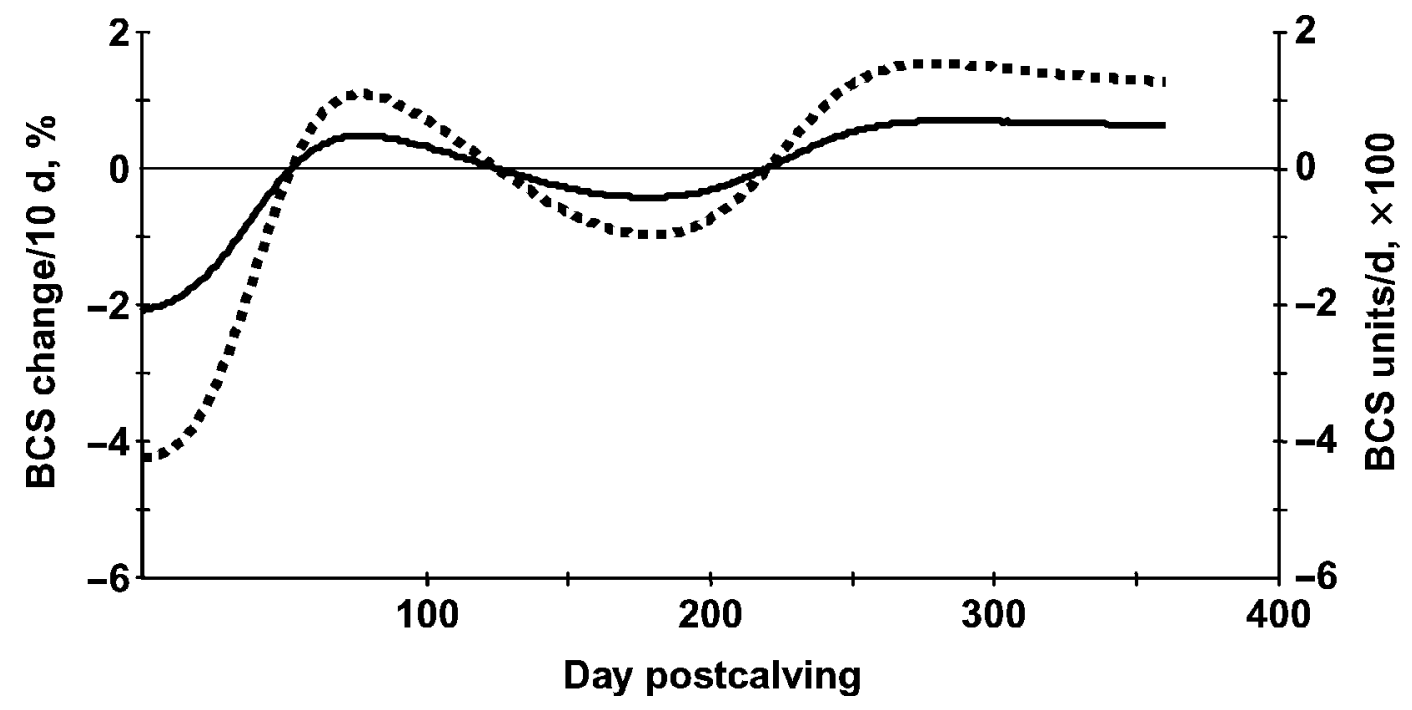

Figure 4. Daily rate of change in BCS (_- ) and 10-d percentage change in BCS (- - - -; rate of change in BCS per $10 \mathrm{~d}$ as a percentage of BCS at the same point in time). 
ROCHE ET AL.

Table 2. Estimates of the parameters of the Roche-Berry-Boston (RBB) function (SE below in parentheses) for different strata of BCS at calving ${ }^{1}$

\begin{tabular}{|c|c|c|c|c|c|c|}
\hline \multirow[b]{2}{*}{ Item } & \multicolumn{6}{|c|}{ Calving BCS } \\
\hline & $\leq 3.5$ & 4 & 4.5 & 5 & 5.5 & $\geq 6.0$ \\
\hline No. of lactations & 108 & 459 & 716 & 598 & 262 & 103 \\
\hline No. of test-day records & 2,434 & 10,738 & 16,680 & 14,032 & 5,993 & 2,378 \\
\hline \multicolumn{7}{|l|}{ Parameter $^{2}$} \\
\hline$I_{1}$ & $\begin{array}{c}3.51 \\
(0.009)\end{array}$ & $\begin{array}{l}4.04 \\
(0.007)\end{array}$ & $\begin{array}{l}4.56 \\
(0.016)\end{array}$ & $\begin{array}{l}4.96 \\
(0.011)\end{array}$ & $\begin{array}{l}5.42 \\
(0.012)\end{array}$ & $\begin{array}{l}6.08 \\
(0.013)\end{array}$ \\
\hline$I_{2}$ & $\begin{array}{l}3.22 \\
(0.0009)\end{array}$ & $\begin{array}{l}3.61 \\
(0.0004)\end{array}$ & $\begin{array}{l}3.81 \\
(0.0004)\end{array}$ & $\begin{array}{l}4.13 \\
(0.0004)\end{array}$ & $\begin{array}{l}4.29 \\
(0.0005)\end{array}$ & $\begin{array}{l}4.92 \\
(0.0010)\end{array}$ \\
\hline$I_{3}$ & $\begin{array}{l}4.72 \\
(0.024)\end{array}$ & $\begin{array}{l}4.90 \\
(0.022)\end{array}$ & $\begin{array}{l}4.97 \\
(0.039)\end{array}$ & $\begin{array}{l}5.13 \\
(0.024)\end{array}$ & $\begin{array}{l}5.37 \\
(0.023)\end{array}$ & $\begin{array}{l}5.70 \\
(0.026)\end{array}$ \\
\hline$I_{4}$ & $\begin{array}{l}2.40 \\
(0.024)\end{array}$ & $\begin{array}{l}2.71 \\
(0.021)\end{array}$ & $\begin{array}{l}2.69 \\
(0.032)\end{array}$ & $\begin{array}{l}2.86 \\
(0.026)\end{array}$ & $\begin{array}{l}2.90 \\
(0.023)\end{array}$ & $\begin{array}{l}3.38 \\
(0.024)\end{array}$ \\
\hline$S L_{1}, \times 1,000$ & $\begin{array}{l}-6.35 \\
(0.462)\end{array}$ & $\begin{array}{l}-6.23 \\
(0.275)\end{array}$ & $\begin{array}{r}-15.86 \\
(0.633)\end{array}$ & $\begin{array}{r}-19.50 \\
(0.371)\end{array}$ & $\begin{array}{c}-28.73 \\
(0.398)\end{array}$ & $\begin{array}{c}-34.80 \\
(0.463)\end{array}$ \\
\hline$S L_{2} \times 1,000$ & $\begin{array}{l}6.67 \\
(0.047)\end{array}$ & $\begin{array}{l}5.26 \\
(0.051)\end{array}$ & $\begin{array}{l}4.53 \\
(0.094)\end{array}$ & $\begin{array}{l}3.64 \\
(0.057)\end{array}$ & $\begin{array}{l}3.83 \\
(0.056)\end{array}$ & $\begin{array}{l}1.23 \\
(0.053)\end{array}$ \\
\hline$S L_{3}, \times 1,000$ & $\begin{array}{l}-4.21 \\
(0.133)\end{array}$ & $\begin{array}{l}-4.39 \\
(0.126)\end{array}$ & $\begin{array}{l}-4.35 \\
(0.249)\end{array}$ & $\begin{array}{l}-4.08 \\
(0.135)\end{array}$ & $\begin{array}{l}-4.53 \\
(0.128)\end{array}$ & $\begin{array}{l}-4.79 \\
(0.154)\end{array}$ \\
\hline$S L_{4}, \times 1,000$ & $\begin{array}{l}5.79 \\
(0.073)\end{array}$ & $\begin{array}{l}5.32 \\
(0.065)\end{array}$ & $\begin{array}{l}5.91 \\
(0.091)\end{array}$ & $\begin{array}{l}5.90 \\
(0.077)\end{array}$ & $\begin{array}{l}6.42 \\
(0.071)\end{array}$ & $\begin{array}{l}5.62 \\
(0.074)\end{array}$ \\
\hline$P T_{1}, \times 1,000$ & $\begin{array}{l}88.26 \\
(6.617)\end{array}$ & $\begin{array}{c}101.58 \\
(6.873)\end{array}$ & $\begin{array}{l}86.37 \\
(5.164)\end{array}$ & $\begin{array}{l}93.87 \\
(4.805)\end{array}$ & $\begin{array}{l}88.87 \\
(3.910)\end{array}$ & $\begin{array}{l}83.56 \\
(4.021)\end{array}$ \\
\hline$P T_{2}, \times 1,000$ & $\begin{array}{l}60.83 \\
(4.635)\end{array}$ & $\begin{array}{l}66.62 \\
(5.119)\end{array}$ & $\begin{array}{l}42.45 \\
(2.819)\end{array}$ & $\begin{array}{l}63.13 \\
(5.427)\end{array}$ & $\begin{array}{l}62.15 \\
(5.767)\end{array}$ & $\begin{array}{l}57.65 \\
(7.098)\end{array}$ \\
\hline$P T_{3}, \times 1,000$ & $\begin{array}{l}67.26 \\
(3.963)\end{array}$ & $\begin{array}{l}59.37 \\
(4.097)\end{array}$ & $\begin{array}{l}39.50 \\
(2.491)\end{array}$ & $\begin{array}{l}47.74 \\
(3.007)\end{array}$ & $\begin{array}{l}66.66 \\
(3.790)\end{array}$ & $\begin{array}{l}69.89 \\
(4.162)\end{array}$ \\
\hline$T T_{1}$ & $\begin{array}{l}27.1 \\
(0.91)\end{array}$ & $\begin{array}{l}36.8 \\
(0.85)\end{array}$ & $\begin{array}{l}30.7 \\
(0.83)\end{array}$ & $\begin{array}{l}31.9 \\
(0.71)\end{array}$ & $\begin{array}{l}31.7 \\
(0.61)\end{array}$ & $\begin{array}{l}23.4 \\
(0.66)\end{array}$ \\
\hline$T T_{2}$ & $\begin{array}{c}140.1 \\
(0.88)\end{array}$ & $\begin{array}{l}134.9 \\
(0.92)\end{array}$ & $\begin{array}{c}133.9 \\
(0.97)\end{array}$ & $\begin{array}{c}132.1 \\
(0.96)\end{array}$ & $\begin{array}{c}129.9 \\
(0.96)\end{array}$ & $\begin{array}{c}134.9 \\
(0.98)\end{array}$ \\
\hline$t t_{2}$ & $\begin{array}{r}228.4 \\
(0.91)\end{array}$ & $\begin{array}{r}224.2 \\
(0.90)\end{array}$ & $\begin{array}{r}232.3 \\
(0.94)\end{array}$ & $\begin{array}{c}229.0 \\
(0.92)\end{array}$ & $\begin{array}{c}226.5 \\
(0.90)\end{array}$ & $\begin{array}{c}220.5 \\
(0.91)\end{array}$ \\
\hline
\end{tabular}

\footnotetext{
${ }^{1} 1$ to 10 scale (Roche et al., 2004).

${ }^{2} I_{x}$ is the intercept (BCS units) of phase $x, S L_{x}$ is the linear slope (BCS change/d) of the profile in phase $x, P T_{x}$ is the phase transition point leaving phase $x$, and $T T_{x}$ is the turning time (d) of the profile between phase $x$ and phase $x+1$.
}

\section{Model Fit to Strata Defined by Parity}

Solutions for the parameters of the RBB model for the different parity strata are summarized in Table 3; the fit of the RBB model to the raw data for each stratum is illustrated in Figure 7 and the strata comparison is presented in Figure 8. Across all strata, the RMSE of the model fit varied from 0.13 to 0.16 BCS units. The $\mathrm{r}^{2}$ of the fit varied from 60 to $72 \%$. The crossing over of profiles was apparent, but appeared isolated to the first-parity cohort. First-parity cows calved at the highest BCS but had the lowest BCS after 240 DIM. The rate of BCS loss directly postpartum $\left(S L_{1}\right)$ did not differ between parities. Timing of the first nadir was later in first-parity cows, with DIM to nadir averaging 53, 41, $45,44,43$, and $41 \mathrm{~d}$ postcalving in first, second, third, fourth, fifth, and $\geq$ sixth parities, respectively. Timing of the midlactation peak was not affected by parity, averaging $135,135,131,128,131$, and $132 \mathrm{~d}$ postcalving in first- to sixth-parity animals, respectively.

\section{Model Fit to Different Nutritional Regimens}

The BCS intercalving profiles and the parameters of the RBB model are outlined in Figure 9 and Table 4, respectively, for cows grazing fresh pasture or fed TMR. The RMSE of the model fit were 0.39 and 0.65 BCS units and the adjusted $\mathrm{r}^{2}$ of the fit were 38 and $58 \%$ for the grazing and TMR-fed animals, respectively. The intercalving profile in Figure 9 indicates a greater BCS at all stages of lactation in cows being fed TMR compared with pasture, and there was no second phase of BCS decline and incline in TMR-fed cows. The first and second intercepts and the slope parameters indicate 

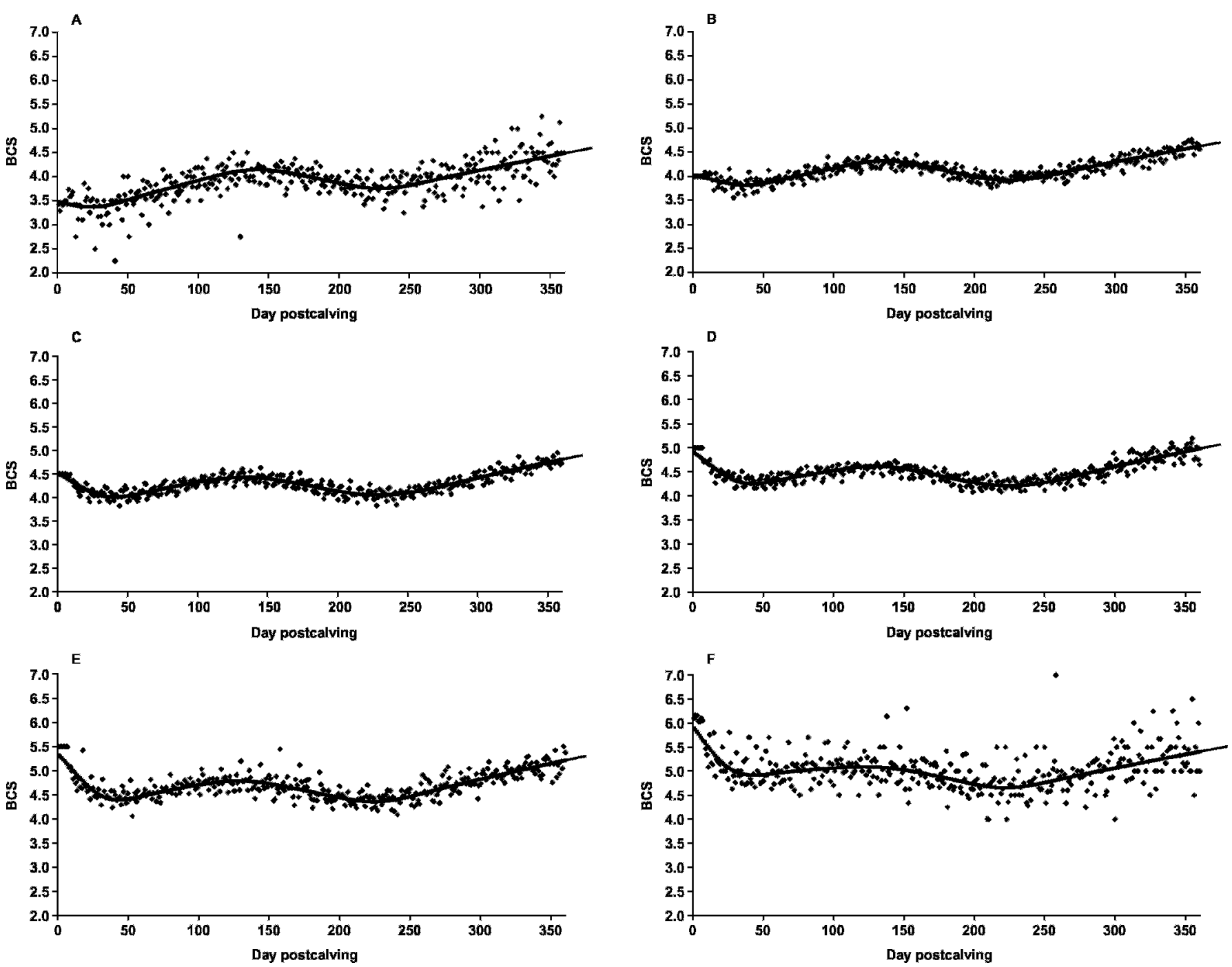

Figure 5. Raw mean BCS (points) and fitted Roche-Berry-Boston function (continuous line) across days postcalving for animals calving at a BCS of (A) $\leq 3.5$, (B) 4.0, (C) 4.5, (D) 5.0, (E) 5.5, and (F) $\geq 6.0$. Body condition score was recorded on a 1 to 10 scale (Roche et al., 2004).

that TMR-fed cows calved at a significantly $(P<0.001)$ greater BCS and lost BCS at a slower $(P<0.001)$ rate than grazing cows. The amount of BCS lost between calving and nadir was greater in pasture-fed cows, and the rate of gain postnadir was greater in TMR-fed cows. The timing of first nadir was 41 and 47 DIM for pasturefed and TMR-fed cows, respectively.

\section{Model Fit to Stocking Rate}

The fit of the RBB model to cows grazing at different stocking rates is illustrated in Figure 10 and the strata comparisons are presented in Figure 11. The model parameters are summarized in Table 5. The RMSE of the fit across the alternative strata varied from 0.17 to 0.33 BCS units. The $r^{2}$ of the fit to the data varied from
29 to $49 \%$. Irrespective of stocking rate, cows exhibited an initial period of BCS loss postcalving and a second period of BCS loss during midlactation. Minimal crossover of BCS intercalving profiles existed among strata (Figure 11), with the height of the profile increasing as the stocking rate declined. Days in milk to first nadir were $28,35,40,35$, and $31 \mathrm{~d}$ for animals stocked at $2.2,2.7,3.2,3.7$, and 4.3 cows/ha, respectively; the corresponding DIM at the midlactation peak were 148, $136,152,139$, and $171 \mathrm{~d}$, respectively.

Calving BCS tended $(P<0.10)$ to decline with stocking rate. Furthermore, there was a tendency for the rate of BCS loss directly postcalving $\left(S L_{1}\right)$ to decrease (i.e., become greater) with increasing stocking rate, resulting in a greater difference in BCS at the first postcalving nadir than existed at calving. The parameters 


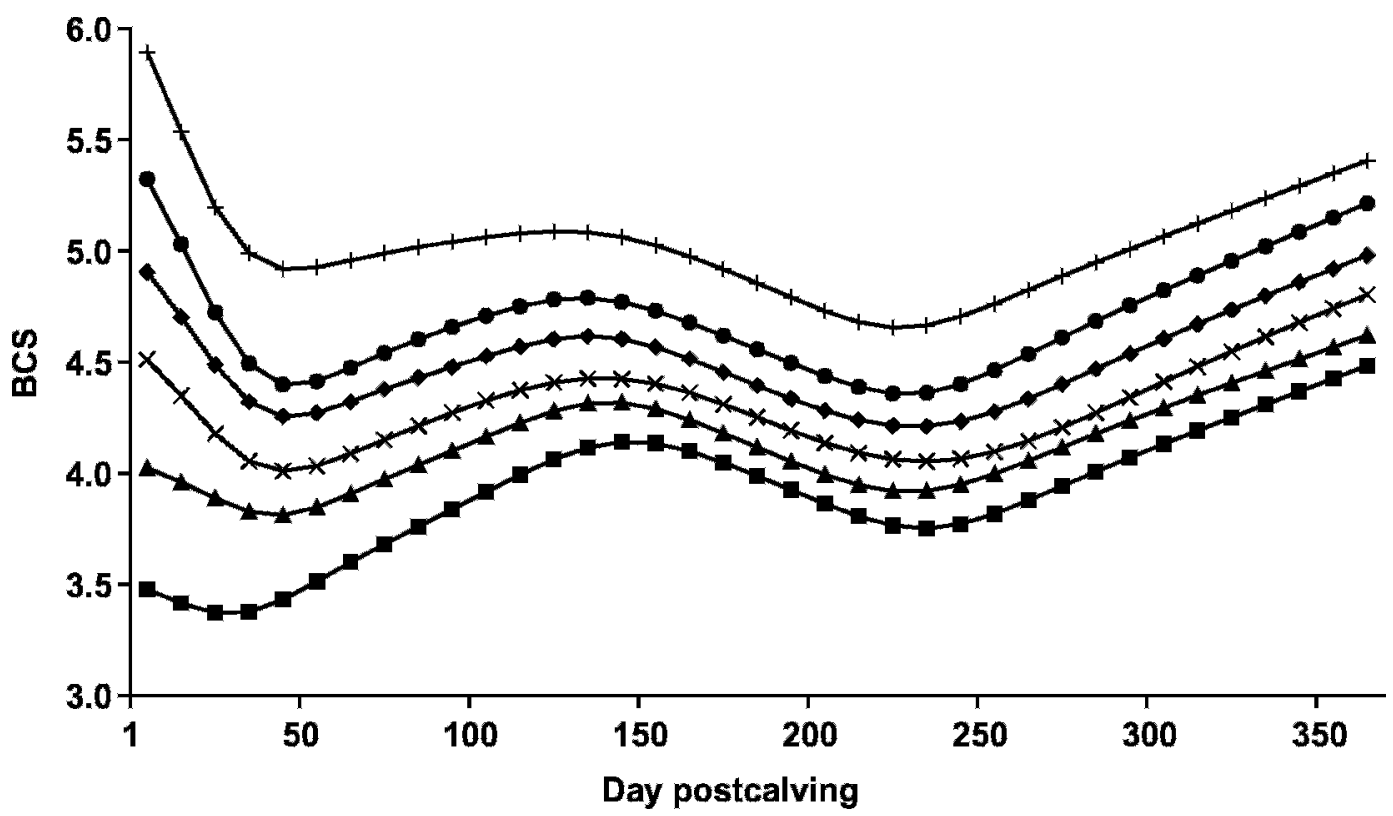

Figure 6. Comparison of BCS intercalving profiles fitted with the Roche-Berry-Boston model for cows calving at a BCS of $\leq 3.5$ ( $\mathbf{\square}), 4.0$ $(\triangleleft), 4.5(\times), 5.0(\diamond), 5.5(\bullet)$, or $\geq 6.0(+)$. Body condition score was recorded on a 1 to 10 scale (Roche et al., 2004).

$S L_{2}$ and $S L_{3}$ were not affected by stocking rate, but the rate of BCS gain following the second nadir $\left(S L_{4}\right)$ declined linearly $(P<0.01)$ with increasing stocking rate, reflecting a slower assent to calving BCS in the more highly stocked herds.

\section{DISCUSSION}

Several researchers have implicated BCS and BCS change as indicators of the (future) health (Roche and Berry, 2006) and fertility status (Beam and Butler, 1999; Buckley et al., 2003; Roche et al., 2007a) of the dairy cow. However, the interval between BCS scoring in published studies varies from weekly (Domecq et al., 1997; Coffey et al., 2002) to every other week (Roche et al., 2006; 2007a), and interassessment intervals can be even greater and less regular in on-farm studies (Buckley et al., 2003). Furthermore, the relatively large increments in which BCS change is measured can lead to fluctuations in the BCS of a cow over time, due to either scorer error or the inability of the scoring system to accommodate more subtle changes in energy and protein stores. This presents a difficulty in accurately estimating important features of the intercalving BCS profile, such as BCS and day postcalving at nadir.

Therefore, the objective of the current study was to develop a mathematical model that would accurately describe the intercalving BCS profile for dairy cows across a diverse range of cow strata and farm systems. The RBB function overcomes a considerable number of the aforementioned shortcomings of BCS measures on farm by smoothing out the random variation and allowing the end user to determine BCS at critical time points when no actual BCS observation may be available.

\section{BCS Intercalving Profiles}

The approach described, of using soft, segmented merging of sequential components of response profiles, has been discussed previously by Grossman et al. (1999) in regard to modeling lactation and extended lactation profiles. Its application has also been highlighted by one of the authors of this paper (R. C. Boston) in relation to the linear disposition of drugs (Orsini et al., 2006). Four distinct phases in the BCS intercalving profile were identified, and functions were generated to accurately model the change in BCS and the transition between BCS in each of the 4 phases. The RBB function reflected the linear superposition of these individual phase functions. Each parameter in the RBB function is identified with a biological process relating to BCS at the start of the phase (intercept points), pattern of BCS change within a phase (direction and slope), approximate timing of phase transitions (turning points), and speed at which 2 phases merge into one another. The RBB function is potentially valuable for describing the BCS profiles of different cohorts (e.g., parity, calving BCS, experimental treatment) objectively, as well as for providing a statistical vehicle to compare the effect 
Table 3. Estimates of the parameters of the Roche-Berry-Boston (RBB) function (SE below in parentheses) across different parities

\begin{tabular}{|c|c|c|c|c|c|c|}
\hline \multirow[b]{2}{*}{ Item } & \multicolumn{6}{|c|}{ Parity } \\
\hline & 1 & 2 & 3 & 4 & 5 & $\geq 6$ \\
\hline No. of lactations & 509 & 383 & 341 & 311 & 260 & 393 \\
\hline No. of test-day records & 11,781 & 9,261 & 8,167 & 7,366 & 6,000 & 8,815 \\
\hline \multicolumn{7}{|l|}{ Parameter $^{1}$} \\
\hline$I_{1}$ & $\begin{array}{l}5.04 \\
(0.014)\end{array}$ & $\begin{array}{c}4.65 \\
(0.012)\end{array}$ & $\begin{array}{l}4.78 \\
(0.010)\end{array}$ & $\begin{array}{c}4.77 \\
(0.009)\end{array}$ & $\begin{array}{c}4.77 \\
(0.010)\end{array}$ & $\begin{array}{l}4.81 \\
(0.010)\end{array}$ \\
\hline$I_{2}$ & $\begin{array}{l}4.06 \\
(0.0002)\end{array}$ & $\begin{array}{l}3.90 \\
(0.0002)\end{array}$ & $\begin{array}{l}3.92 \\
(0.0004)\end{array}$ & $\begin{array}{l}3.98 \\
(0.0006)\end{array}$ & $\begin{array}{l}3.95 \\
(0.0006)\end{array}$ & $\begin{array}{l}3.96 \\
(0.0006)\end{array}$ \\
\hline$I_{3}$ & $\begin{array}{c}4.98 \\
(0.026)\end{array}$ & $\begin{array}{c}4.91 \\
(0.043)\end{array}$ & $\begin{array}{c}4.87 \\
(0.022)\end{array}$ & $\begin{array}{l}5.25 \\
(0.024)\end{array}$ & $\begin{array}{c}5.10 \\
(0.023)\end{array}$ & $\begin{array}{c}4.95 \\
(0.023)\end{array}$ \\
\hline$I_{4}$ & $\begin{array}{l}2.72 \\
(0.027)\end{array}$ & $\begin{array}{l}2.57 \\
(0.034)\end{array}$ & $\begin{array}{l}2.68 \\
(0.021)\end{array}$ & $\begin{array}{l}2.74 \\
(0.022)\end{array}$ & $\begin{array}{c}2.52 \\
(0.023)\end{array}$ & $\begin{array}{c}2.67 \\
(0.023)\end{array}$ \\
\hline$S L_{1}, \times 1,000$ & $\begin{array}{r}-18.11 \\
\quad(0.465)\end{array}$ & $\begin{array}{l}-17.14 \\
\quad(0.477)\end{array}$ & $\begin{array}{r}-19.10 \\
(0.314)\end{array}$ & $\begin{array}{r}-15.88 \\
(0.303)\end{array}$ & $\begin{array}{r}-18.19 \\
(0.323)\end{array}$ & $\begin{array}{l}-20.06 \\
(0.354)\end{array}$ \\
\hline$S L_{2}, \times 1,000$ & $\begin{array}{c}3.07 \\
(0.063)\end{array}$ & $\begin{array}{l}3.52 \\
(0.074)\end{array}$ & $\begin{array}{l}3.80 \\
(0.052)\end{array}$ & $\begin{array}{c}4.80 \\
(0.060)\end{array}$ & $\begin{array}{l}4.16 \\
(0.055)\end{array}$ & $\begin{array}{l}4.15 \\
(0.052)\end{array}$ \\
\hline$S L_{3}, \times 1,000$ & $\begin{array}{l}-3.83 \\
(0.153)\end{array}$ & $\begin{array}{l}-4.05 \\
(0.275)\end{array}$ & $\begin{array}{c}-3.52 \\
(0.123)\end{array}$ & $\begin{array}{c}-5.14 \\
(0.136)\end{array}$ & $\begin{array}{c}-4.62 \\
(0.131)\end{array}$ & $\begin{array}{c}-3.49 \\
(0.129)\end{array}$ \\
\hline$S L_{4}, \times 1,000$ & $\begin{array}{l}5.71 \\
(0.080)\end{array}$ & $\begin{array}{c}6.91 \\
(0.096)\end{array}$ & $\begin{array}{c}6.29 \\
(0.066)\end{array}$ & $\begin{array}{c}6.32 \\
(0.067)\end{array}$ & $\begin{array}{c}6.91 \\
(0.070)\end{array}$ & $\begin{array}{l}6.51 \\
(0.072)\end{array}$ \\
\hline$P T_{1}, \times 1,000$ & $\begin{array}{l}67.25 \\
(4.822)\end{array}$ & $\begin{array}{c}105.46 \\
\quad(6.481)\end{array}$ & $\begin{array}{l}92.94 \\
(4.714)\end{array}$ & $\begin{array}{l}89.84 \\
(5.210)\end{array}$ & $\begin{array}{l}96.7 \\
(4.840)\end{array}$ & $\begin{array}{l}90.95 \\
(4.734)\end{array}$ \\
\hline$P T_{2}, \times 1,000$ & $\begin{array}{l}47.77 \\
(4.547)\end{array}$ & $\begin{array}{l}44.99 \\
(2.205)\end{array}$ & $\begin{array}{l}60.61 \\
(6.083)\end{array}$ & $\begin{array}{l}63.46 \\
(5.139)\end{array}$ & $\begin{array}{l}68.77 \\
(5.540)\end{array}$ & $\begin{array}{l}74.54 \\
(5.817)\end{array}$ \\
\hline$P T_{3}, \times 1,000$ & $\begin{array}{l}52.26 \\
(2.742)\end{array}$ & $\begin{array}{l}49.38 \\
(2.540)\end{array}$ & $\begin{array}{l}57.27 \\
(4.057)\end{array}$ & $\begin{array}{l}58.72 \\
(3.674)\end{array}$ & $\begin{array}{l}58.36 \\
(3.580)\end{array}$ & $\begin{array}{l}51.44 \\
(3.860)\end{array}$ \\
\hline$T T_{1}$ & $\begin{array}{l}34.3 \\
(0.78)\end{array}$ & $\begin{array}{l}29.8 \\
(0.77)\end{array}$ & $\begin{array}{l}35.7 \\
(0.67)\end{array}$ & $\begin{array}{l}36.6 \\
(0.70)\end{array}$ & $\begin{array}{l}34.7 \\
(0.69)\end{array}$ & $\begin{array}{l}29.5 \\
(0.70)\end{array}$ \\
\hline$T T_{2}$ & $\begin{array}{c}139.3 \\
(0.96)\end{array}$ & $\begin{array}{c}136.6 \\
(0.98)\end{array}$ & $\begin{array}{c}130.2 \\
(0.97)\end{array}$ & $\begin{array}{l}129.0 \\
(0.95)\end{array}$ & $\begin{array}{c}132.1 \\
(0.95)\end{array}$ & $\begin{array}{c}133.0 \\
(0.96)\end{array}$ \\
\hline$T T_{3}$ & $\begin{array}{r}238.6 \\
(0.92)\end{array}$ & $\begin{array}{r}227.2 \\
\quad(0.90)\end{array}$ & $\begin{array}{l}225.0 \\
(0.91)\end{array}$ & $\begin{array}{l}221.0 \\
(0.88)\end{array}$ & $\begin{array}{r}224.7 \\
\quad(0.88)\end{array}$ & $\begin{array}{l}227.1 \\
\quad(0.91)\end{array}$ \\
\hline
\end{tabular}

${ }^{1} I_{x}$ is the intercept (BCS units) of phase $x, S L_{x}$ is the linear slope (BCS change/d) of the profile in phase $x, P T_{x}$ is the phase transition point leaving phase $x$, and $T T_{x}$ is the turning time (d) of the profile between phase $x$ and phase $x+1$.

of alternate treatments on BCS change throughout the intercalving period.

The model presented describes the intercalving profile of BCS across time, explaining a large proportion of the variation in the data set. Roche et al. (2006) proposed that the BCS profile across a lactation is a close approximation to a horizontally inverted milk lactation profile, declining during early lactation and increasing following a nadir at 40 to 80 DIM. The authors proceeded to fit an exponential function (Wilmink, 1987) that was derived for use in milk lactation profiles. However, as depicted in Figure 1, a second period of NEBAL is evident in grazing dairy cows in midlactation, irrespective of calving BCS, parity, or stocking rate. This phenomenon would not be modeled when using the post-turning point (i.e., first nadir) linear regression incorporated in the Wilmink function. The inability to accurately model this feature in midlactation is also a limitation of other approaches to describing lactation profiles (Wood, 1976; Friggens et al., 2004). Although it is true that diphasic models, random regression models (Weigel et al., 1992; Coffey et al., 2002; Banos et al., 2005), or both provide empirical alternatives, the output parameters are rarely identifiable with biological traits.

Furthermore, this second decline in BCS between 122 and 171 DIM is not unique to the data sets used in the present study. The mean BCS profile presented by Pryce and Harris (2006) from grazing systems also indicated the initiation of a midlactation decline in BCS. Similarly, although not as pronounced, a plateau in the profile of BCS gain during midlactation was observed by Berry et al. (2006) when using random regressions fitted to BCS data from grazing dairy cows. Fontaneli et al. (2005) also reported, consistent with the thesis that this midlactation undulation in BCS in grazing 

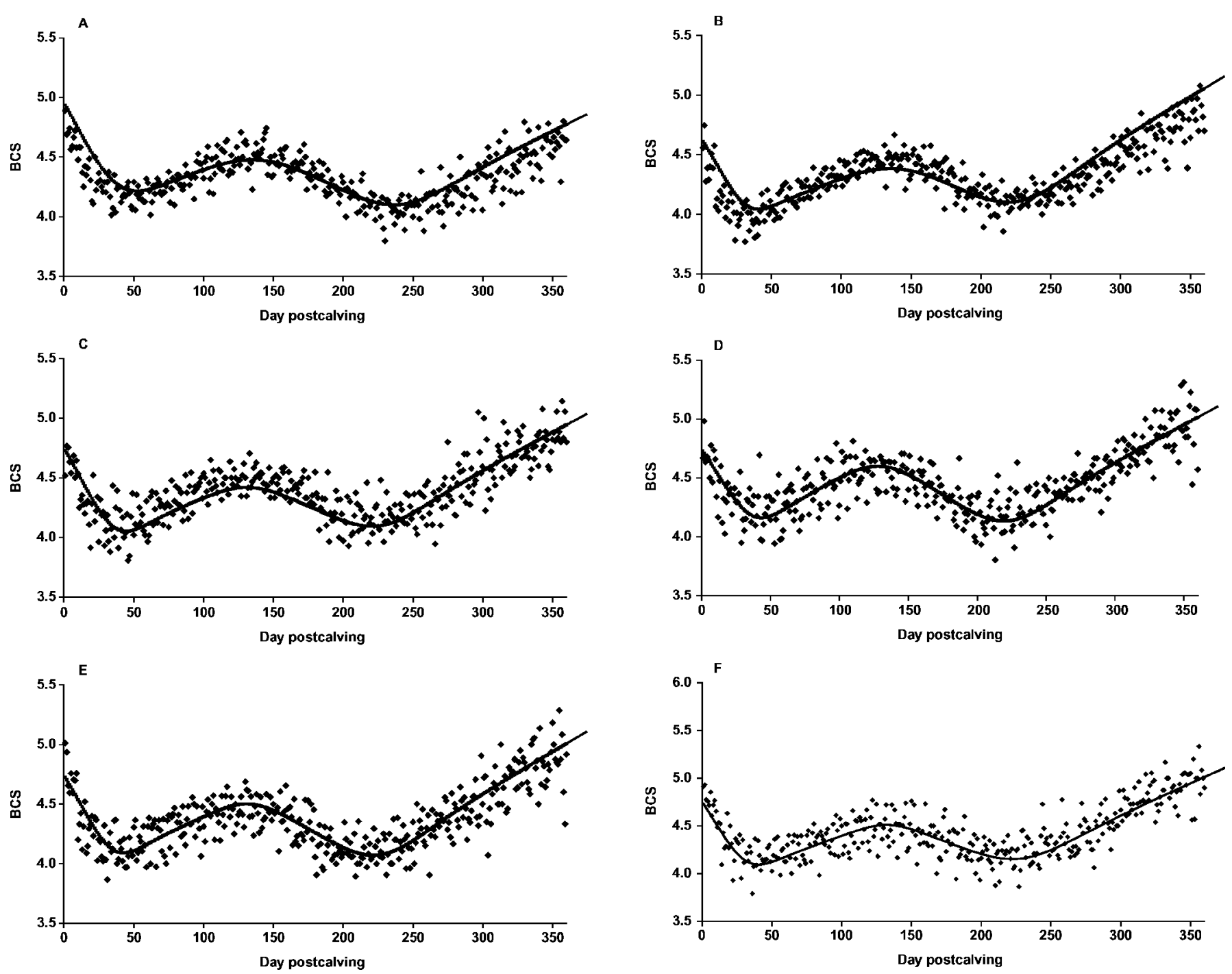

Figure 7. Raw mean BCS (points) and fitted Roche-Berry-Boston function (continuous line) across days postcalving for (A) first-, (B) second-, (C) third-, (D) fourth-, (E) fifth-, and (F) sixth- to eighth-parity animals. Body condition score was recorded on a 1 to 10 scale (Roche et al., 2004).

dairy cows is real, this tendency in midlactation in their BW profile. In direct contrast, the data collated from cows fed TMR in the present study indicated no such undulation in midlactation, in agreement with data previously reported from similar systems (Mao et al., 2004). To our knowledge, this midlactation undulation has not been previously quantified or discussed.

The initial period of loss and gain is an expected mammalian evolutionary adaptation to provide nutrients to the neonate through milk. Genetic selection priorities have resulted in an increase in mammary gland metabolic rate and nutrient use, and the concurrent delayed onset of hyperphagia, along with other consequences of genetic selection, has resulted in the catabolism of tissue stores to facilitate lactational demands being met (Bauman and Currie, 1980). This is consistent with both the observed patterns of BCS loss and the predicted parameters in the present study. It is also consistent with the data from a serial slaughter study undertaken by Gibb et al. (1992), who reported a decline in empty BW and carcass weight for 5 to 8 wk postcalving, before increasing linearly to 29 wk postcalving, when the study ended. The weight of omental and mesenteric fat followed the same trend. Furthermore, the quantity of BCS lost from calving to nadir is consistent with previous reports (Roche et al., 2006; 2007a), and DIM to nadir are similar to those reported by Roche et al. (2006).

This difference between the reported BCS profile across farm systems presented here and across most 


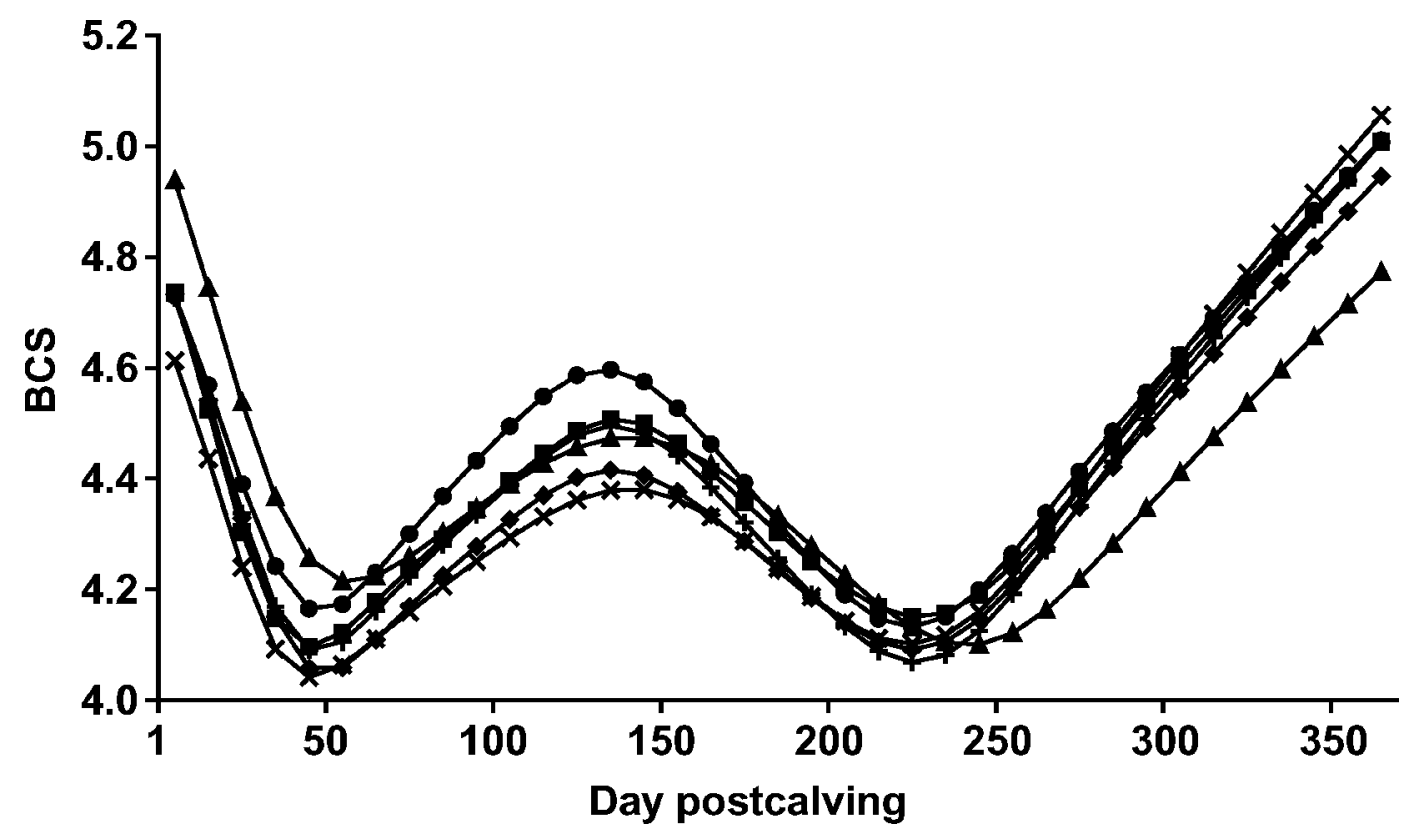

Figure 8. Comparison of BCS intercalving profiles fitted with the Roche-Berry-Boston model for first- $(\mathbf{\Delta})$, second- $(\times)$, third- $(\bullet)$, fourth(๑), fifth- (+), or sixth- to eighth- (ロ) parity animals. Body condition score was recorded on a 1 to 10 scale (Roche et al., 2004).

published studies is the midlactation period of NEBAL evident under seasonal calving grazing systems. The most plausible predisposing factor for this second period of decline in BCS is midlactation feed quality. Van
Soest (1996) reported a decline in forage digestibility and a reduction in forage intake potential with increasing ambient temperatures; such climatic changes would be expected in midlactation (summer) in seasonal

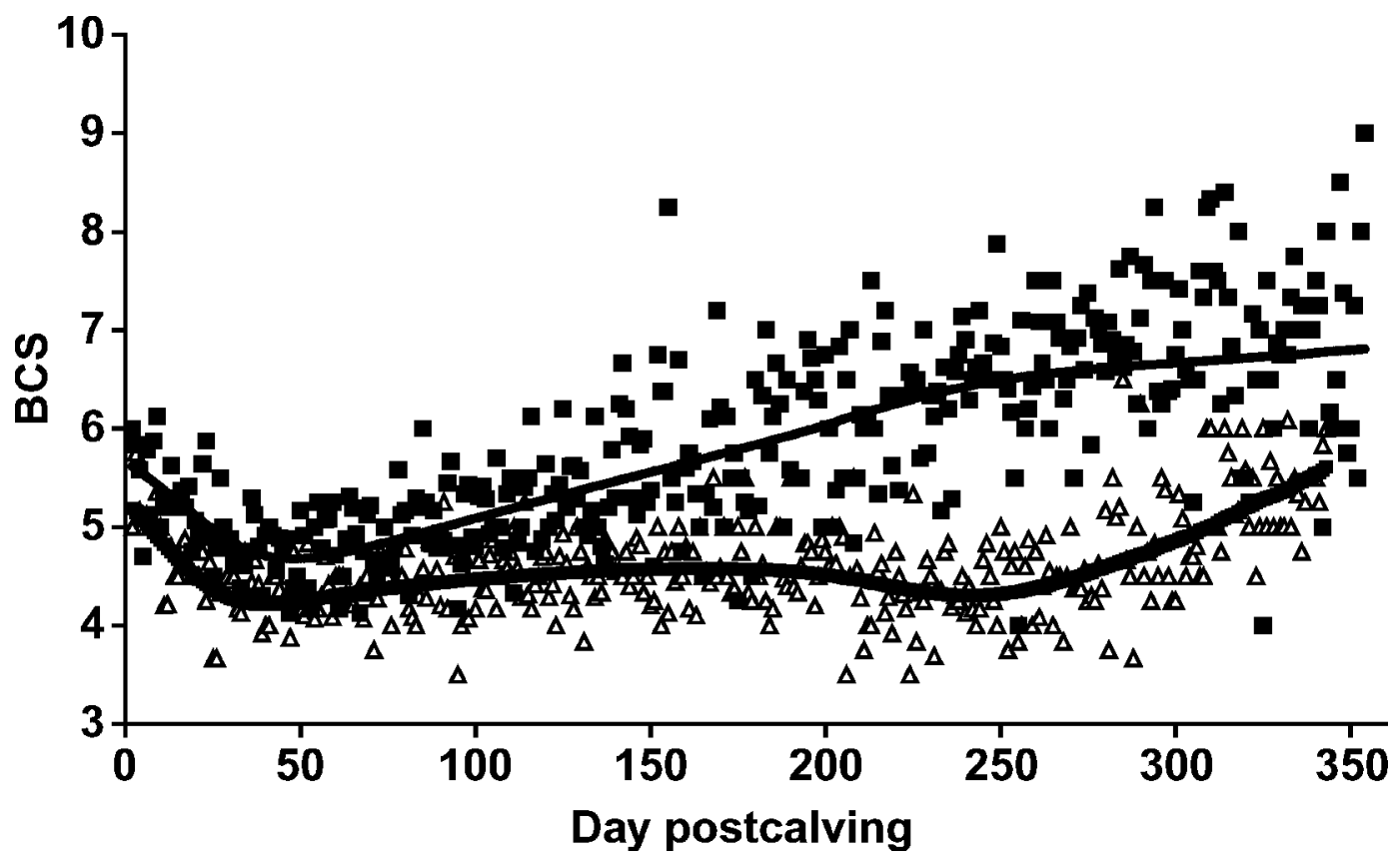

Figure 9. Comparison of BCS intercalving profiles fitted with the Roche-Berry-Boston (RBB) model for animals fed grazed grass (raw data, $\triangle$; fitted RBB function is the continuous heavy line) or TMR (raw data, $\mathbf{\square}$; fitted RBB function is the continuous line). Body condition score was recorded on a 1 to 10 scale (Roche et al., 2004). 
Table 4. Estimates of the parameters of the Roche-Berry-Boston (RBB) function (SE below in parentheses) for cows grazing pasture or fed a TMR

\begin{tabular}{|c|c|c|}
\hline Item & Pasture & TMR \\
\hline $\begin{array}{l}\text { No. of lactations } \\
\text { No. of test-day records }\end{array}$ & $\begin{array}{r}103 \\
2,005\end{array}$ & $\begin{array}{r}108 \\
2,107\end{array}$ \\
\hline $\begin{array}{l}\text { Parameter }^{1} \\
I_{1}\end{array}$ & $\begin{array}{l}5.22 \\
(0.0036)\end{array}$ & $\begin{array}{l}5.81 \\
(0.0003)\end{array}$ \\
\hline$I_{2}$ & $\begin{array}{l}4.13 \\
(0.000830)\end{array}$ & $\begin{array}{l}4.13 \\
(0.000000)\end{array}$ \\
\hline$I_{3}$ & $\begin{array}{l}4.45 \\
(0.010)\end{array}$ & $\begin{array}{l}4.37 \\
(0.003)\end{array}$ \\
\hline$I_{4}$ & $\begin{array}{l}0.55 \\
(0.033)\end{array}$ & $\begin{array}{l}5.92 \\
(0.001)\end{array}$ \\
\hline$S L_{1}, \times 1,000$ & $\begin{array}{l}-38.69 \\
(0.002)\end{array}$ & $\begin{array}{l}-13.16 \\
(0.001)\end{array}$ \\
\hline$S L_{2}, \times 1,000$ & $\begin{array}{l}3.21 \\
(0.000034)\end{array}$ & $\begin{array}{l}9.59 \\
(0.000001)\end{array}$ \\
\hline$S L_{3}, \times 1,000$ & $\begin{array}{l}0.66 \\
(0.0003)\end{array}$ & $\begin{array}{l}5.91 \\
(0.0001)\end{array}$ \\
\hline$S L_{4}, \times 1,000$ & $\begin{array}{l}14.04 \\
(0.0003)\end{array}$ & $\begin{array}{l}2.47 \\
(0.0000)\end{array}$ \\
\hline$P T_{1}, \times 1,000$ & $\begin{array}{l}94.85 \\
(0.057)\end{array}$ & $\begin{array}{l}84.17 \\
(0.005)\end{array}$ \\
\hline$P T_{2}, \times 1,000$ & $\begin{array}{l}29.02 \\
(0.005)\end{array}$ & $\begin{array}{l}38.51 \\
(0.006)\end{array}$ \\
\hline$P T_{3}, \times 1,000$ & $\begin{array}{l}62.88 \\
(0.054)\end{array}$ & $\begin{array}{l}44.42 \\
(0.007)\end{array}$ \\
\hline$T T_{1}$ & $\begin{array}{l}25.9 \\
(0.85)\end{array}$ & $\begin{array}{l}25.4 \\
(0.39)\end{array}$ \\
\hline$T T_{2}$ & $\begin{aligned} 130.3 & (0.99)\end{aligned}$ & $\begin{aligned} & 159.2 \\
&(0.99)\end{aligned}$ \\
\hline$T T_{3}$ & $\begin{aligned} 232.5 \\
(0.93)\end{aligned}$ & $\begin{aligned} 228.1 \\
(0.93)\end{aligned}$ \\
\hline
\end{tabular}

${ }^{1} I_{x}$ is the intercept (BCS units) of phase $x, S L_{x}$ is the linear slope (BCS change/d) of the profile in phase $x, P T_{x}$ is the phase transition point leaving phase $x$, and $T T_{x}$ is the turning time (d) of the profile between phase $x$ and phase $x+1$.

spring-calving systems. Consistent with this view, Roche and Berry (unpublished data) have documented systematic seasonal variation in grass quality during the year from a research herd in New Zealand located in the vicinity of where the studies included in the present study were undertaken. Pasture ADF and NDF were greatest and pasture $\mathrm{OM}$ digestibility and $\mathrm{ME}$ were lowest in the period from December to February, coinciding with midlactation. The reduced DMI potential (Van Soest, 1996) and lower energy density of the pasture would result in reduced energy intakes. Such a decline in energy intake has been shown to reduce the expression of hepatic growth hormone receptor-1A (Breier et al., 1988), "uncouple" the somatotropic axis (elevated growth hormone but reduced IGF-I; McGuire et al., 1995), and likely increase body tissue mobilization because of the increase in circulating growth hor- mone (Bauman and Currie, 1980). This tendency to lose body condition in midlactation in grazing systems is potentially a large inefficiency, and the critical feed quality levels at which it occurs require further investigation if mitigation strategies to avoid this are to be devised.

Irrespective of the reason for the second decline in $\mathrm{BCS}$ in midlactation, the RBB function overcomes the restrictive assumption of a single linear approach to postnadir BCS by structurally supporting what is evident in the actual data. Furthermore, in achieving this, the RBB function quantifies rates of change within the phases and phase transition times. This facilitates the use of RBB in research projects investigating the influence of a mid- or late-lactation diet. In addition, although the flexibility attributed to the parameters in the RBB function are sufficient to model the undulations in the intercalving BCS profile accurately, they are not so flexible as to allow the function to follow BCS patterns attributable to random variation, as could be expected with polynomial or spline functions. This ability to accurately model a nonlinear change in BCS postnadir provides for greater use of the RBB function, because it allows researchers to model the effect of nutrition or farm management effects in early, mid-, or late lactation on the full intercalving BCS profile.

\section{Strata of BCS at Calving}

The consistent ranking in BCS throughout the intercalving period when stratified on BCS at calving is consistent with previous studies reporting moderate correlations between BCS at different stages of lactation (Roche et al., 2007a). Similarly, it agrees with previous genetic analyses of BCS in grazing HolsteinFriesian dairy cows that BCS is under moderate genetic control and that cows have predetermined genetic profiles for BCS across lactation (Berry et al., 2003; Pryce and Harris, 2006). Berry et al. (2003) reported strong genetic correlations $(>0.66)$ between BCS at different stages of lactation and suggested that genes affecting BCS in early lactation have a similar function on BCS in late lactation.

Despite this consistent ranking in BCS throughout lactation, an inverse association was found between the linear rate of BCS loss (i.e., the $S L_{1}$ parameter) and $\mathrm{BCS}$ at calving. This reflects a greater rate of BCS loss in fatter cows and a greater amount of BCS lost as calving BCS increases. These results are consistent with previous studies (see review by Broster and Broster, 1998; Roche et al., 2007a). This negative association between calving BCS and amount of condition lost in early lactation is also consistent with the results of calorimetric studies undertaken by Holter et al. (1990), 

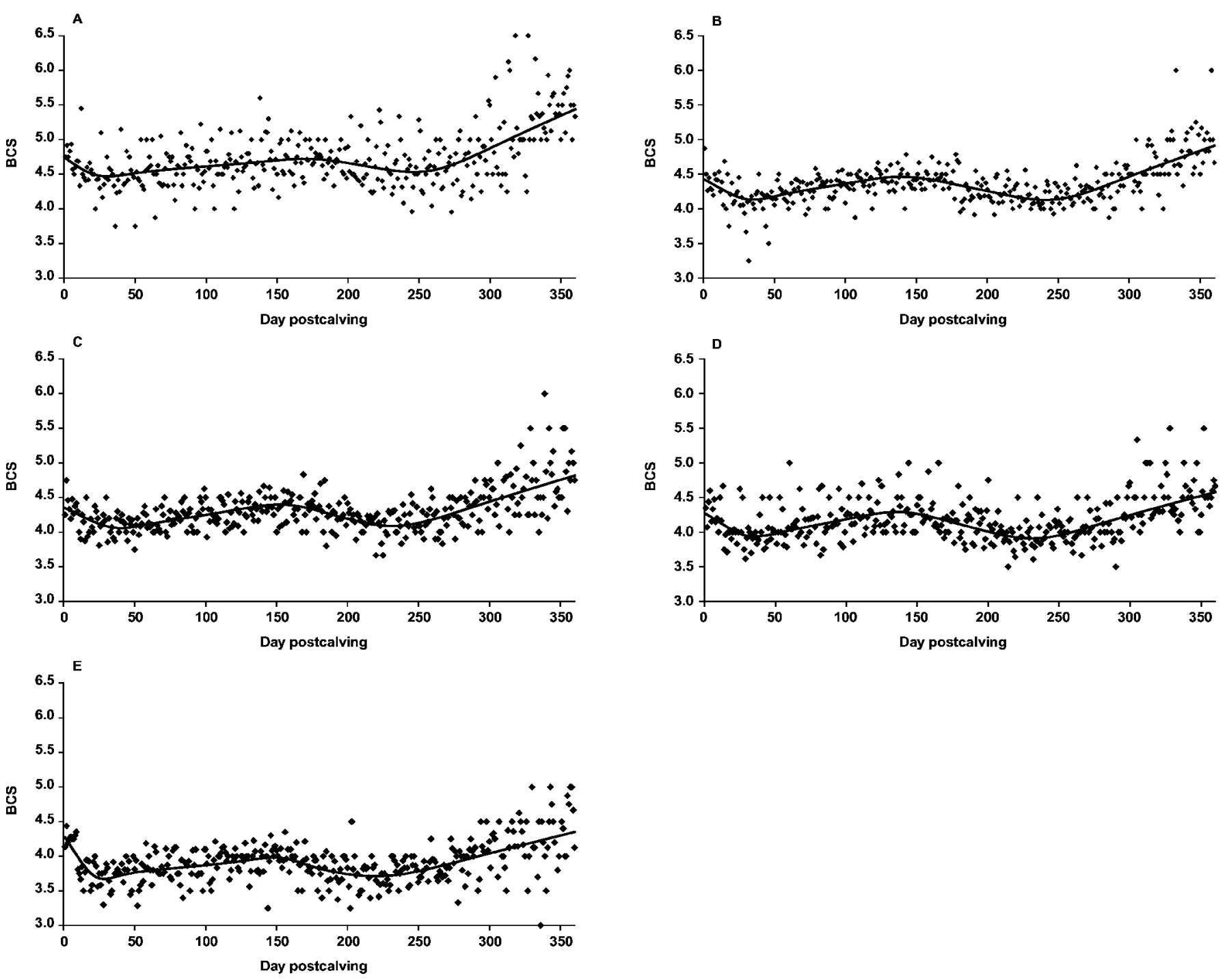

Figure 10. Raw mean BCS (points) and fitted Roche-Berry-Boston function (continuous line) across days postcalving for animals stocked at (A) 2.2, (B) 2.7, (C) 3.2, (D) 3.7, and (E) 4.3 cows/ha. Body condition score was recorded on a 1 to 10 scale (Roche et al., 2004).

who reported that cows with a lower calving BCS exhibited a lower NEBAL. In addition, the period of NEBAL declined in a nonlinear fashion with decreasing calving BCS in the current study, and the rate of BCS replenishment post first nadir increased linearly as calving BCS declined. The sum of these parameter relationships was that the difference in BCS at calving declined as the lactation progressed. Furthermore, there were no obvious effects of calving BCS on the midlactation decline in BCS, or on the rate of BCS replenishment post second nadir. Hence, BCS at calving appears to only affect the subsequent lactation profile up to approximately $150 \mathrm{~d}$ postcalving in grazing cows.

\section{Strata of Parity}

The similarity in the intercalving profiles of BCS for cows of different parities is consistent with previous studies on dairy cows fed predominantly on grazed grass (Berry et al., 2006) or TMR (Mao et al., 2004). However, a notable difference in the BCS profile between parities across most experiments (Mao et al., 2004; Berry et al., 2006), including the present study, is the tendency for BCS at nadir to be lower in older parity animals. The fitting of the RBB model to the data allowed an accurate quantification and comparison of the different attributes of the intercalving profile across parities. The parameters indicate that the greater BCS 


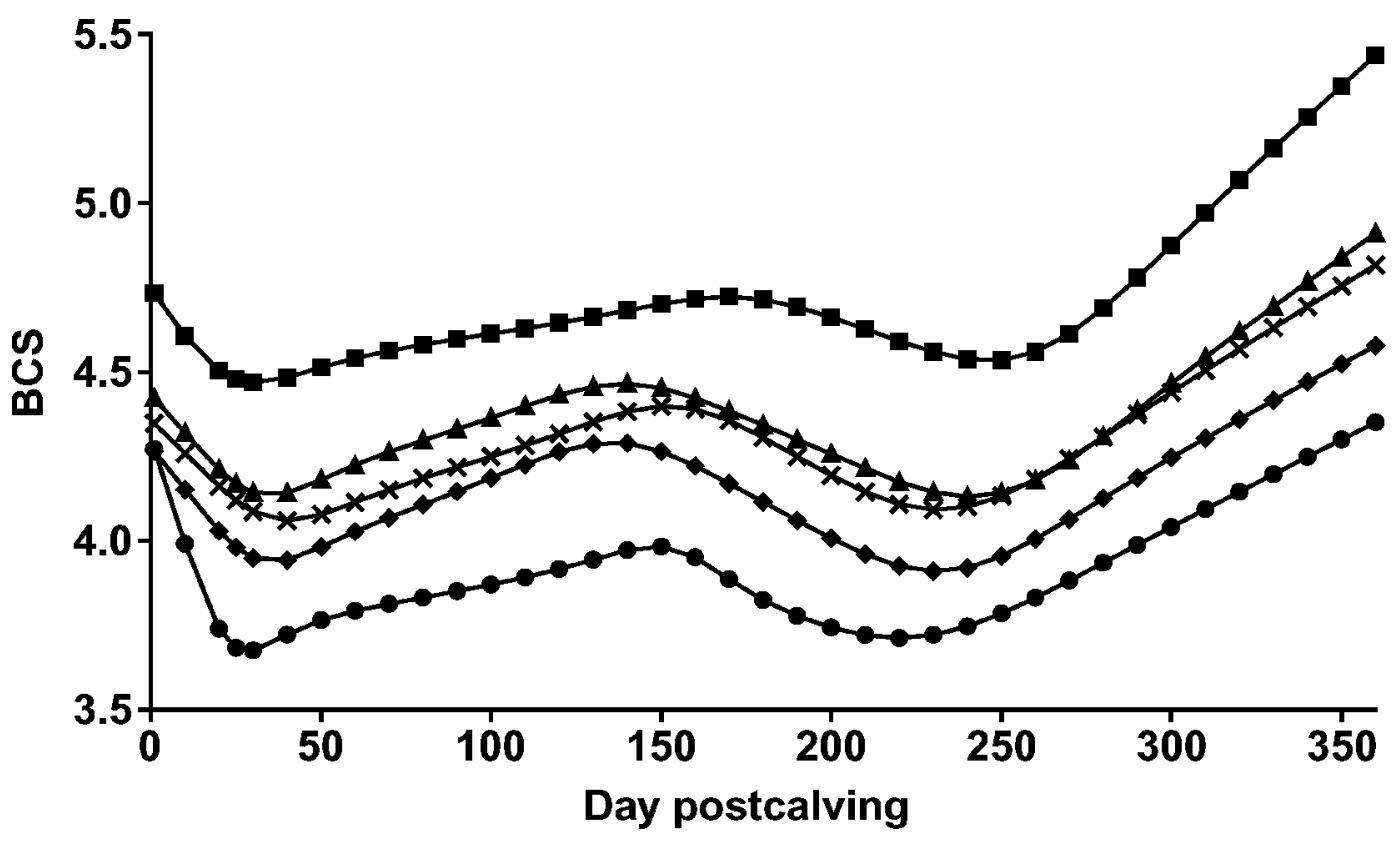

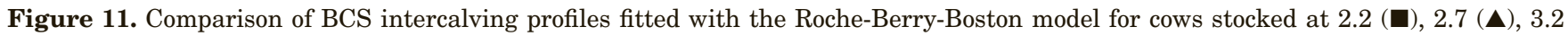
$(\times), 3.7(\diamond)$, and 4.3 cows/ha $(\bullet)$. Body condition score was recorded on a 1 to 10 scale (Roche et al., 2004).

at nadir in primiparous animals was largely an artifact of their greater BCS at calving, at least in the present study, because the linear rate of BCS loss postcalving in first-parity cows was similar to older cows. Firstparity cows lost BCS for a longer period of time in the current study, possibly as a result of the previously defined positive relationship between calving BCS.

More noteworthy, however, is the evident failure of primiparous cows to gain BCS postnadir as effectively as their multiparous companions. Therefore, although fatter cows at calving generally remain fatter throughout the intercalving period (Figure 2), first-parity animals calve at the greatest BCS, but by 250 DIM they have the lowest BCS and their rate of BCS gain in late lactation $\left(S L_{4}\right)$ is slower than that of later parity cows. This is an important management consideration, at least for grazing production systems, because it reflects a need for the preferential treatment of first-parity cows in late lactation to ensure they are at the desired BCS for their second calving event.

\section{Strata of Nutritional Treatment}

Consistent with the effects reported by Roche et al. (2006), nutrition affected the shape of the BCS intercalving profile in the current study. Cows calving at lower stocking rates were in better condition but lost less BCS than their contemporaries in more highly stocked herds, despite the correlation reported earlier between calving BCS and postcalving BCS loss, and they gained BCS at a slower rate than more highly stocked herds. The most plausible explanation for this is the lower availability of pasture in the highly stocked herds both in early lactation, resulting in greater BCS loss, and in late lactation, resulting in less available energy for BCS increase. This effect of energy availability on BCS reduction and increase is consistent with the greater nadir and smaller BCS loss reported by Roche et al. (2006) in grazing dairy cows receiving supplementary concentrates, compared with those receiving no supplementary concentrate feeds.

However, one noteworthy difference between the results of Roche et al. (2006) and the BCS profile differences between cows receiving pasture or TMR in the current study is the effect of nutrition on the rate of BCS loss postcalving. Roche et al. (2006) reported no effect of supplementary concentrates on the rate of BCS loss postcalving, with the difference at nadir being the result of a shorter period of NEBAL. However, the current results indicate a greater rate of loss of BCS postcalving in grazing cows compared with those fed TMR. This is despite the cows fed TMR calving with greater BCS, a factor already reported to increase the rate of BCS loss. This inconsistency may be a result of nonnutritional differences between the different systems. Kolver and Muller (1998) modeled the difference in milk yield between cows fed TMR and those fed pasture. Their conclusion was that $89 \%$ of the difference was not due to the nutritional differences between the 2 diets, but was due largely to a greater DMI in TMR- 
Table 5. Estimates of the parameters of the Roche-Berry-Boston (RBB) function (SE below in parentheses) from a multiyear experiment (1998 to 2000) that compared animal performance at different stocking rates under grazing

\begin{tabular}{|c|c|c|c|c|c|}
\hline \multirow[b]{2}{*}{ Item } & \multicolumn{5}{|c|}{ Stocking rate } \\
\hline & $\begin{array}{c}2.2 \\
\text { cows/ha }\end{array}$ & $\begin{array}{c}2.7 \\
\text { cows/ha }\end{array}$ & $\begin{array}{c}3.2 \\
\text { cows/ha }\end{array}$ & $\begin{array}{c}3.7 \\
\text { cows/ha }\end{array}$ & $\begin{array}{c}4.3 \\
\text { cows/ha }\end{array}$ \\
\hline No. of lactations & 108 & 120 & 114 & 108 & 114 \\
\hline No. of test-day records & 2,491 & 2,742 & 2,523 & 2,293 & 2,365 \\
\hline \multicolumn{6}{|l|}{ Parameter $^{1}$} \\
\hline$I_{1}$ & $\begin{array}{l}4.78 \\
(0.0001)\end{array}$ & $\begin{array}{l}4.45 \\
(0.0001)\end{array}$ & $\begin{array}{l}4.37 \\
(0.0001)\end{array}$ & $\begin{array}{l}4.29 \\
(0.0001)\end{array}$ & $\begin{array}{l}4.32 \\
(0.0001)\end{array}$ \\
\hline$I_{2}$ & $\begin{array}{r}-13.56 \\
(0.0003)\end{array}$ & $\begin{array}{l}-10.53 \\
\quad(0.0001)\end{array}$ & $\begin{array}{l}-8.61 \\
(0.0001)\end{array}$ & $\begin{array}{l}-11.18 \\
\quad(0.0001)\end{array}$ & $\begin{array}{l}-28.89 \\
\quad(0.0003)\end{array}$ \\
\hline$I_{3}$ & $\begin{array}{l}4.47 \\
(0.0000)\end{array}$ & $\begin{array}{l}4.07 \\
(0.0000)\end{array}$ & $\begin{array}{l}3.96 \\
(0.0000)\end{array}$ & $\begin{array}{l}3.84 \\
(0.0000)\end{array}$ & $\begin{array}{l}3.69 \\
(0.0000)\end{array}$ \\
\hline$I_{4}$ & $\begin{array}{l}1.41 \\
(0.0000)\end{array}$ & $\begin{array}{l}2.81 \\
(0.0000)\end{array}$ & $\begin{array}{l}2.80 \\
(0.0000)\end{array}$ & $\begin{array}{l}3.24 \\
(0.0000)\end{array}$ & $\begin{array}{l}1.69 \\
(0.0000)\end{array}$ \\
\hline$S L_{1}, \times 1,000$ & $\begin{array}{l}4.99 \\
(0.0012)\end{array}$ & $\begin{array}{l}4.86 \\
(0.0004)\end{array}$ & $\begin{array}{l}4.78 \\
(0.0011)\end{array}$ & $\begin{array}{l}4.82 \\
(0.0005)\end{array}$ & $\begin{array}{l}4.04 \\
(0.0025)\end{array}$ \\
\hline$S L_{2}, \times 1,000$ & $\begin{array}{l}-1.67 \\
(0.0000)\end{array}$ & $\begin{array}{l}-2.89 \\
(0.0000)\end{array}$ & $\begin{array}{l}-2.79 \\
(0.0000)\end{array}$ & $\begin{array}{l}-3.90 \\
(0.0000)\end{array}$ & $\begin{array}{l}-1.16 \\
(0.0001)\end{array}$ \\
\hline$S L_{3}, \times 1,000$ & $\begin{array}{l}2.24 \\
(0.0013)\end{array}$ & $\begin{array}{l}2.38 \\
(0.0007)\end{array}$ & $\begin{array}{l}2.63 \\
(0.0007)\end{array}$ & $\begin{array}{l}2.67 \\
(0.0005)\end{array}$ & $\begin{array}{l}2.52 \\
(0.0004)\end{array}$ \\
\hline$S L_{4}, \times 1,000$ & $\begin{array}{l}8.88 \\
(0.0000)\end{array}$ & $\begin{array}{l}7.02 \\
(0.0000)\end{array}$ & $\begin{array}{l}6.09 \\
(0.0000)\end{array}$ & $\begin{array}{l}5.31 \\
(0.0000)\end{array}$ & $\begin{array}{l}5.09 \\
(0.0000)\end{array}$ \\
\hline$P T_{1}, \times 1,000$ & $\begin{array}{l}96.16 \\
(0.0370)\end{array}$ & $\begin{array}{l}110.10 \\
(0.0435)\end{array}$ & $\begin{array}{l}97.78 \\
(0.0481)\end{array}$ & $\begin{array}{l}115.72 \\
\quad(0.0364)\end{array}$ & $\begin{array}{l}147.02 \\
\quad(0.0472)\end{array}$ \\
\hline$P T_{2}, \times 1,000$ & $\begin{array}{l}73.43 \\
(0.0728)\end{array}$ & $\begin{array}{l}71.96 \\
(0.0454)\end{array}$ & $\begin{array}{l}74.31 \\
(0.0466)\end{array}$ & $\begin{array}{l}71.44 \\
(0.0382)\end{array}$ & $\begin{array}{l}117.68 \\
\quad(0.0788)\end{array}$ \\
\hline$P T_{3}, \times 1,000$ & $\begin{array}{l}54.44 \\
(0.0169)\end{array}$ & $\begin{array}{l}53.99 \\
(0.0145)\end{array}$ & $\begin{array}{l}52.79 \\
(0.0209)\end{array}$ & $\begin{array}{l}55.98 \\
(0.0177)\end{array}$ & $\begin{array}{l}51.34 \\
(0.0026)\end{array}$ \\
\hline$T T_{1}$ & $\begin{array}{l}22.05 \\
(0.8497)\end{array}$ & $\begin{array}{l}30.91 \\
(0.7714)\end{array}$ & $\begin{array}{l}33.25 \\
(0.7547)\end{array}$ & $\begin{array}{l}29.73 \\
(0.7022)\end{array}$ & $\begin{array}{l}22.31 \\
(0.3216)\end{array}$ \\
\hline$T T_{2}$ & $\begin{array}{l}171.31 \\
(0.9562)\end{array}$ & $\begin{array}{l}139.28 \\
(0.9377)\end{array}$ & $\begin{array}{l}156.05 \\
(0.8842)\end{array}$ & $\begin{array}{l}136.59 \\
(0.9177)\end{array}$ & $\begin{array}{l}157.13 \\
\quad(0.6683)\end{array}$ \\
\hline$T T_{3}$ & $\begin{array}{l}256.01 \\
\quad(0.8956)\end{array}$ & $\begin{array}{l}246.81 \\
\quad(0.8660)\end{array}$ & $\begin{array}{l}231.10 \\
\quad(0.8619)\end{array}$ & $\begin{array}{l}232.63 \\
\quad(0.8669)\end{array}$ & $\begin{array}{l}219.21 \\
\quad(0.9254)\end{array}$ \\
\hline
\end{tabular}

${ }^{1} I_{x}$ is the intercept (BCS units) of phase $x, S L_{x}$ is the linear slope (BCS change/d) of the profile in phase $x, P T_{x}$ is the phase transition point leaving phase $x$, and $T T_{x}$ is the turning time (d) of the profile between phase $x$ and phase $x+1$.

fed cows, a greater energy expenditure in grazing cows because of grazing and walking, and a greater milk fat content. Further research is required to quantify the effect of nutrition on the BCS profile, enabling better management of BCS in early lactation and possibly capturing the reported benefits in reproduction (Buckley et al., 2003; Roche et al., 2007a).

\section{CONCLUSIONS}

The RBB function offers compelling strengths with regard to its application in characterizing intercalving BCS. Its parameters are directly estimable from the data and, in themselves, characterize important properties of the BCS profile for the stratum under investigation. In each data set, BCS followed the accepted profile of postcalving loss followed by a postnadir gain. However, the raw data highlighted a second period of loss in midlactation in seasonal spring-calving cows grazing fresh pasture, but not those fed TMR. This loss was followed by a subsequent period of gain. The ability of the RBB function to accurately identify biological attributes of the intercalving BCS profile in a group of cows will make it possible to relate the variables derived from the function to economically and socially important traits, such as production, fertility, health, and welfare.

\section{ACKNOWLEDGMENTS}

The authors gratefully acknowledge the help afforded them by J. Lancaster and C. Leydon-Davis. This work 
was partially funded by New Zealand dairy farmers through Dairy InSight (Wellington, New Zealand).

\section{REFERENCES}

Banos, G., M. P. Coffey, and S. Brotherstone. 2005. Modeling daily energy balance of dairy cows in the first three lactations. J. Dairy Sci. 88:2226-2237.

Bauman, D. E., and B. Currie. 1980. Partitioning of nutrients during pregnancy and lactation: A review of mechanisms involving homeostasis and homeorhesis. J. Dairy Sci. 63:1514-1529.

Beam, S. W., and W. R. Butler. 1999. Energy balance, metabolic hormones, and early postpartum follicular development in dairy cows fed prilled lipid. J. Dairy Sci. 81:121-131.

Berry, D. P., F. Buckley, P. Dillon, R. D. Evans, and R. F. Veerkamp. 2003. Genetic parameters for body condition score, body weight, milk yield, and fertility estimated using random regression models. J. Dairy Sci. 86:3704-3717.

Berry, D. P., K. A. Macdonald, K. Stafford, L. Matthews, and J. R. Roche. 2007. Associations between body condition score, body weight, and somatic cell count and clinical mastitis in seasonally calving dairy cattle. J. Dairy Sci. 90:637-648.

Berry, D. P., R. F. Veerkamp, and P. Dillon. 2006. Phenotypic profiles for body weight, body condition score, energy intake, and energy balance across different parities and concentrate feeding levels. Livest. Sci. 104:1-12.

Breier, B. H., P. D. Gluckman, and J. J. Bass. 1988. The somatotrophic axis in young steers: Influence of nutritional status and oestradiol-17 $\beta$ on hepatic high- and low-affinity somatotrophic binding sites. J. Endocrinol. 116:169-177.

Broster, W. H., and V. J. Broster. 1998. Body score of dairy cows. J. Dairy Res. 65:155-173.

Buckley, F., K. O'Sullivan, J. F. Mee, R. D. Evans, and P. Dillon. 2003. Relationships among milk yield, body condition, cow weight, and reproduction in spring-calved Holstein-Friesians. J. Dairy Sci. 86:2308-2319.

Coffey, M. P., G. Simm, and S. Brotherstone. 2002. Energy balance profiles for the first three lactations of dairy cows estimated using random regression models. J. Dairy Sci. 85:2669-2678.

Domecq, J. J., A. L. Skidmore, J. W. Lloyd, and J. B. Kaneene. 1997. Relationship between body condition scores and milk yield in a large dairy herd of high-yielding Holstein cows. J. Dairy Sci. 80:101-112.

Fontaneli, R. S., L. E. Sollenberger, R. C. Littell, and C. R. Stapes. 2005. Performance of lactating dairy cows managed on pasturebased or in freestall barn-feeding systems. J. Dairy Sci. 88:1264-1276.

Friggens, N. C., K. L. Ingvartsen, and G. C. Emmans. 2004. Prediction of body lipid change in pregnancy and lactation. J. Dairy Sci. 87:988-1000.

Gibb, M. J., W. E. Irvings, M. S. Dhanoa, and J. D. Sutton. 1992. Changes in body components of autumn-calving Holstein Friesian cows over the first 29 weeks of lactation. Anim. Prod. 5:339-360.

Grossman, M., S. M. Hartz, and W. J. Koops. 1999. Persistency of lactation yield. J. Dairy Sci. 82:2192-2197.

Holter, J. B., M. J. Slotnick, H. H. Hayes, C. K. Bozak, W. E. Urban Jr., and M. L. McGilliard. 1990. Effect of prepartum dietary energy on condition score, postpartum energy, nitrogen partitions, and lactation production responses. J. Dairy Sci. 73:3502-3511.

Huber, P. J. 1964. Robust estimation of a location parameter. Annals Math Stat. 35:73-101.
Kolver, E. S., and L. D. Muller. 1998. Performance and nutrient intake of high-producing Holstein cows consuming pasture or a total mixed ration. J. Dairy Sci. 81:1403-1411.

Kolver, E. S., J. R. Roche, M. J. de Veth, P. Thorne, and A. R. Napper. 2002. Total mixed ration versus pasture diets: Evidence of a genotype $\times$ diet interaction. Proc. N. Z. Soc. Anim. Prod. 62:246-251.

Macdonald, K. A., and J. W. Penno. 1998. Management decision rules to optimise milksolids production on dairy farms. Proc. N. Z. Soc. Anim. Prod. 58:132-135.

Mao, I. L., K. Sloniewski, P. Madsen, and J. Jensen. 2004. Changes in body condition score and in its genetic variation during lactation. Livest. Prod. Sci. 89:55-65.

McGuire, M. A., D. E. Bauman, D. A. Dwyer, and W. S. Cohick. 1995 Nutritional modulation of the somatotropin/insulin-like growth factor system: Response to feed deprivation in lactating cows. J. Nutr. 125:493-502.

Orsini, J. A., P. J. Moate, K. Kuersten, L. R. Soma, and R. C. Boston. 2006. Pharmacokinetics of fentanyl delivered transdermally in healthy adult horses-Variability among horses and its clinical implications. J. Vet. Pharmacol. Therap. 29:539-546.

Pryce, J. E., and B. L. Harris. 2006. Genetics of body condition score in New Zealand dairy cows. J. Dairy Sci. 89:4424-4432.

Roche, J. R., P. G. Dillon, C. R. Stockdale, L. H. Baumgard, and M. J. VanBaale. 2004. Relationships among international body condition scoring systems. J. Dairy Sci. 87:3076-3079.

Roche, J. R., and D. P. Berry. 2006. Periparturient, climatic, animal, and management factors influencing the incidence of milk fever in grazing systems. J. Dairy Sci. 89:2775-2783.

Roche, J. R., D. P. Berry, and E. S. Kolver. 2006. Holstein-Friesian strain and feed effects on milk production, body weight, and body condition score profiles in grazing dairy cows. J. Dairy Sci. 89:3532-3543.

Roche, J. R., J. M. Lee, K. M. Macdonald, and D. P. Berry. 2007b. Relationships among body condition score, body weight, and milk production variables in pasture-based dairy cows. J. Dairy Sci. 90:3802-3815.

Roche, J. R., K. A. Macdonald, C. R. Burke, and D. P. Berry. 2007a Associations among body condition score, body weight, and reproductive performance in seasonal-calving pasture-based dairy cattle. J. Dairy Sci. 90:376-391.

StataCorp. 2005. Stata 9.0. Social Science Network and Data Services. StataCorp., College Station, TX.

Stefanovski, D., P. J. Moate, and R. C. Boston. 2003. WinSAAM: A windows-based compartmental modeling system. Metabolism 52:1153-1166.

St-Pierre, N. R. 2001. Invited review: Integrating quantitative findings from multiple studies using mixed model methodology. J. Dairy Sci. 84:741-755.

Van Soest, P. J. 1996. Environment and forage quality. Pages 1-9 in Proc. Cornell Nutr. Conf. Feed Manuf., Cornell Univ., Ithaca, NY.

Waltner, S. S., J. P. McNamara, and J. K. Hillers. 1993. Relationships of body condition score to production variables in high-producing Holstein dairy cattle. J. Dairy Sci. 76:3410-3419.

Weigel, K. A., B. A. Craig, T. R. Bidwell, and D. M. Bates. 1992. Comparison of alternative diphasic lactation curve models under bovine somatotropin administration. J. Dairy Sci. 75:580-589.

Wilmink, J. B. M. 1987. Adjustment of lactation yield for age at calving in relation to level of production. Livest. Prod. Sci. 16:321-334.

Wood, P. D. P. 1976. Algebraic models of the lactation curves for milk, fat and protein production, with estimates of seasonal variation. Anim. Prod. 22:35-40. 